No 3981

Studia nad Autorytaryzmem i Totalitaryzmem 42, nr 1

Wrocław 2020

https://doi.org/10.19195/2300-7249.42.1.1

TOMASZ SIKORSKI

ORCID: 0000-0002-3090-0793

Uniwersytet Szczeciński

t.sikorski@poczta.fm

URSZULA KOZŁOWSKA

ORCID: 0000-0001-5444-5847

Uniwersytet Szczeciński

urszula.kozlowska@usz.edu.pl

\title{
Medical care and sanitation, hygiene and living conditions in German (Nazi) concentration sub-camp Konzentrationslager Stutthof - Aussenlager Pölitz
}

\begin{abstract}
The article analyzes the sanitary and hygienic conditions of living and medical care at Konzentrationslager Stutthof - Aussenlager Pölitz - a branch of the Stutthof central camp. The sub-camp in Police was created with a view to supplying cheap labour to a synthetic gasoline factory, which was a strategic plant of the German war economy. The health condition of prisoners in concentration camps always remained bad, but the health problems of the prisoners in Police resulted not only from terrible sanitary, hygienic, and living conditions, but also from the difficult working conditions in the factory. So far, the issues of interest to us have not found wider interest among researchers who focused on the so-called "Camps", apart from the so-called small — affiliate camps. The following research questions were asked: How did medical care function in the German (Nazi) sub-camp Konzentrationslager Stutthof - Aussenlager Pölitz? What were the sanitary, living and hygienic conditions in the German (Nazi) sub-camp Konzentrationslager Stutthof - Aussenlager Pölitz? In preparing this article the author used research methods characteristic for historical sciences, such as external and internal evaluation of sources; the dogmatic method, which seeks casual connections of a more complex nature than simple time-related connections, and comparative research. The analysis was based on archival materials of the Institute of National Remembrance, especially the Archives of the Branch Office of the Commission For the Prosecution of Crimes Against The Polish Nation of the Institute of National Remembrance in Szczecin (primarily testimony reports and witness accounts, factual documentation), memories and literature of the subject (Polish, German, and English). Based on the source material and subject literature it was proved that: 1) The way the sub-camp in Pölitz operated depended on the requirements of the German arms industry.
\end{abstract}

Studia nad Autorytaryzmem i Totalitaryzmem 42, nr 1, 2020

C for this edition by CNS 
It was created to provide cheap labor for a synthetic fuel factory (Chemische Werke Hydropetroleum Industrie Gesellschaft), a strategic plant for the German war industry. 2) Prisoners of concentration camps were never in good health, but health problems of prisoners in Pölitz were caused not only by poor sanitation, hygiene, and living conditions, but also by harsh working conditions in the factory. 3) The health conditions developed by prisoners from the KL Stutthof - Aussenlager Pölitz could be divided into 4 groups: a) illnesses related to the living conditions in the camp, typical for most concentration camps, b) illnesses resulting from hunger and total exhaustion, c) injuries caused by beating, and d) illnesses resulting from workplace contamination. The operation of the Pölitz camp could be divided into two periods: one when the camp (at that time "the summer camp") was still under construction, and the other - its actual operation - when the winter camp was established with extended camp infrastructure. However, regardless of the time, prisoners always suffered from hunger, exhausting work beyond their capabilities and various illnesses.

Keywords: totalitarianism, German (Nazi) Konzentrationslager Stutthof - Aussenlager Pölitz sub-camp, living conditions, medical care, hygiene.

\section{Introduction}

This article describes medical care, sanitation, hygiene, and living conditions in Aussenlager Pölitz, a sub-camp of the central camp in Stutthof located in Pölitz, today named Police (Poland). ${ }^{1}$ When talking about the current state of research on Konzentrationslager Stutthof we have to pay special attention to the works of Marek Orski, ${ }^{2}$ Krzysztof Dunin-Wąsowicz, ${ }^{3}$ Konrad Ciechanowski (and co-authors), ${ }^{4}$

1 Additionally, the Pomeranian Province also hosted sub-camps of Ravensbrück and Natzweiler-Struthof concentration camps.

2 Cf. for example: M. Orski, Obywatele francuscy w obozie koncetracyjnym Stutthof w latach 1941-1945, Gdańsk 2010; idem, Niewolnicza praca więźniów obozu koncentracyjnego Stutthof w latach 1939-1945: organizacja pracy i metody eksploatacji sity roboczej, Gdańsk 1999; idem, Czesi, Stowacy i Jugosłowianie w KL Stutthof, Gdańsk 1997; idem, Amerykanie w obozie koncentracyjnym Stutthof, Gdańsk 1996; idem, Włosi w obozie Koncentracyjnym Stutthof, Gdańsk 1996; idem, Belgowie, Holendrzy i Luksemburczycy w obozie koncentracyjnym Stutthof, Gdańsk 1996; idem, Il campo di concentramento di Stutthof (1939-1945), Milano 2010; idem, Filie obozu koncentracyjnego Stutthof w latach 1939-1945, Gdańsk 2004; idem, Przedsiębiorstwa SS i firmy prywatne — najemcy sity roboczej obozu koncentracyjnego Stutthof w latach 1939-1945, Gdańsk 2001; idem, Organisation und Ordnungsprinzipien des Lagers Stutthof, [in:] Die nationalsozialistischen Konzentrationslager: Entwicklung und Struktur, ed. U. Herbert, K. Orth, Ch. Dieckmann, Göttingen 1998; idem, Wykaz podobozów i większych komand zewnętrzych, [in:] Stutthof. Hitlerowski obóz koncetracyjny, ed. J. Ciechanowski et al., Warzsawa 1988.

3 K. Dunin-Wąsowicz, Obóz koncetracyjny Stutthof, Gdynia 1966 (2nd ed. — Gdańsk 1977); idem, Stutthof, Warszawa 1981; idem, Stutthof. Ze wspomnień więźnia obozu koncentracyjnego, Sztutowo 2011. We also have to mention some memoirs and recollections by KL Stutthof's prisoners: W. Gajdus, Nr 29998 opowiada, Kraków 1962; W. Gębik, Z diabłami na ty, Gdańsk 1972; W. Wnuk, Bytem z wami, Warszawa 1975; B. Sruoga, Los więźniów, Gdynia 1965; W. Mitura, Wspomnienia więźnia Stutthofu, Warszawa 1978.

4 K. Ciechanowski et al., Stutthof: hitlerowski obóz koncentracyjny, Warszawa 1988.

Studia nad Autorytaryzmem i Totalitaryzmem 42, nr 1, 2020

(C) for this edition by CNS 
Mirosław Gliński, ${ }^{5}$ Maria Przyłucka, ${ }^{6}$ Janina Grabowska, ${ }^{7}$ Marcin Owsiński, ${ }^{8}$ Elżbieta Grot, ${ }^{9}$ and Danuta Drywa. ${ }^{10}$ Among Western researchers discussing these issues (usually in a broader context) were: Daniel Blatman, ${ }^{11}$ Paul Matussek, ${ }^{12}$ Karin Orth, ${ }^{13}$ Maria Blitz, ${ }^{14}$ Wolfgang Benz, ${ }^{15}$ Trudi Birger, ${ }^{16}$ and Ruth Alton. ${ }^{17}$ Worth mentioning are also the interesting recollections of Olaf W. Walle, a Norwegian prisoner of Stutthof. ${ }^{18}$ The research on Aussenlager Pölitz itself is, on the other hand, much less advanced. Still Bogdan Frankiewicz's works on concentration and labour camps (and forced labour) ${ }^{19}$ in Western Pomerania are worth mentioning as well as contributory articles by Maria E. Jezierska, ${ }^{20}$ Agnieszka Kłys, ${ }^{21}$ Jan Antoni

${ }^{5}$ M. Gliński, Organizacja obozu koncentracyjnego Stutthof (1 września 1939-9 maja 1945), “Zeszyty Muzeum Stutthof” 1979, no. 3; idem, Organizacja i obsada personalna szpitala w obozie koncentracyjnym Stutthof, "Zeszyty Muzeum Stutthof” 1976, no. 1; idem, Podobozy obozu Stutthof, [in:] Obozy hitlerowskie na ziemiach polskich. Informator encyklopedyczny, Warszawa 1979; idem, Podobozy i większe komanda zewnętrzne KL Stutthof (1939-1945), [in:] K. Ciechanowski et al., op. cit.

6 M. Przyłucka, Praca więźniów w obozie koncentracyjnym Stutthof, "Zeszyty Muzeum Stutthof" 1977, no. 2.

7 J. Grabowska, Stutthof - Ein Konzentrationslager vor den Toren Danzigs, Bremen 1995; idem, Marsz śmierci. Ewakuacja piesza więźniów KL Stutthof i jego podobozów 25 stycznia-3 maja 1945, Gdańsk 1992.

${ }^{8}$ M. Owsiński, Polscy więźniowie polityczni w obozie Stutthof 1939-1945, Toruń 2001.

9 E. Grot, Rejs śmierci. Ewakuacja morska więźniów KL Stutthof 1945 r., Gdańsk 1993.

10 D. Drywa, Zagłada Żydów w obozie koncentracyjnym Stutthof (wrzesień 1939-maj 1945), Gdańsk 2001.

11 D. Blatman, The Death Marches. The Final Phase of Nazi Genocide, Cambridge, MA 2011.

12 P. Matussek, Internment in Concentration Camps and Its Consequences, Berlin-Hamburg-New York 1975.

13 K. Orth, Die Konzentrationslager-SS. Soziokulturelle Analysen und biographische Studien, Göttingen 2000; idem, Die Konzentrationslager-SS, München 2004.

14 M. Blitz, Endzeit in Ostpreußen. Ein beschwiegenes Kapitel des Holocaust, Berlin 2010.

15 W. Benz, B. Distel, Der Ort des Terrors. Geschichte der nationalsozialistischen Konzentrationslager, München 2005-2009.

16 T. Birger, Im Angesicht des Feuers. Wie ich der Hölle des Konzentrationslagers entkam, München 1990.

17 R. Alton, Deportiert von den Nazis. Berlin - Lodz - Auschwitz - Stutthof - Dresden, Bielefeld 2009.

18 O.R. Walle, Norsk politi biggtrad. Stutthof - Polities Historie 1939-1945, Oslo 1946.

19 B. Frankiewicz, Hitlerowskie obozy pracy przymusowej oraz obozy karne i jenieckie na terenie Szczecina w latach drugiej wojny światowej, "Przegląd Zachodniopomorski” 1965, no. 4; idem, Obozy hitlerowskie na ziemi szczecińskiej w latach 1939-1945, "Studia nad Faszyzmem i Zbrodniami Hitlerowskimi” 2, 1975; idem, Praca przymusowa na Pomorzu Zachodnim, w latach II wojny światowej, Poznań 1969; idem, Cudzoziemscy robotnicy przymusowi w Szczecinie w latach 1939-1945, "Kronika Szczecina" 2001, no. 20; idem, Materiały do dziejów polskich i cudzoziemskich robotników przymusowych w Archiwum Państwowym w Szczecinie, "Szczeciński Informator Archiwalny" 1999, no. 9.

20 M. Jezierska, Obozy w Policach, "Biuletyn Głównej Komisji Badania Zbrodni Hitlerowskich w Polsce" 15, 1965. See also eadem, Ucieczki z obozu koncentracyjnego Stutthof na tle dokumentów, "Stutthof. Zeszyty Muzeum" 1990, no. 10.

21 A. Kłys, Z Pawiaka do Polic. Więźniowie z Pawiaka w obozie koncentracyjnym Stutthof i podobozie Police k/Szczecina, "Niepodległość i Pamięć" 2015, no. 4 (52); idem, Z Pawiaka do

Studia nad Autorytaryzmem i Totalitaryzmem 42, nr 1, 2020

(C) for this edition by CNS 
Kłys, ${ }^{22}$ Stanisław Olejniczak, ${ }^{23}$ Czesław Gołowacz, ${ }^{24}$ Stefan Cichoń, ${ }^{25}$ Andrzej Zientarski, ${ }^{26}$ Paweł Szulc, ${ }^{27}$ and Paweł Knap. ${ }^{28}$ The published memoirs of Józef Jagodziński, a prisoner of Aussenlager Pölitz, make an important addition to the current state of research. ${ }^{29}$ However, the subject literature still lacks an analysis of medical care, sanitation, and hygiene in the camp. ${ }^{30}$ Despite many valuable works (especially by M. Orski, Bolesław Waluk, ${ }^{31}$ and Maciej Lambert ${ }^{32}$ ) the gap still

Polic. Więźniowie z Pawiaka w obozie koncentracyjnym Stutthof i podobozie Police k/Szczecina, [in:] Historia - ludzie - pamięć, ed. T. Skoczek, Warszawa 2016.

22 J.A. Kłys, Außenlager Stutthof, "Zabytki” 6-7, 2008.

23 S. Olejniczak, Jeszcze w sprawie obozu w Policach, "Za Wolność i Lud" 1959, no. 12.

24 C. Gołowacz, Na miejscu kaźni w Policach, "Wolność i Lud” 1964, no. 3 (216).

25 S. Cichoń, SS-Sonderlager w Policach. Szczecińska filia Stutthofu, "Głos Szczeciński" 1964, no. 94.

26 A. Zientarski, Obozy hitlerowskie na Pomorzu Zachodnim w okresie 1939-1940, "Biuletyn Głównej Komisji Badania Zbrodni Hitlerowskich w Polsce” 31, 1982.

27 P. Szulc, Polickie obozy w latach drugiej wojny światowej, [in:] Z dziejów Polic, SzczecinPolice 2007.

28 P. Knap, Druga strona medalu. Bolesław Kaczyński (1908-1963), "Pamięć i Przyszłość" 2013 , no. 3 .

29 J. Jagodziński, Bunkry na ruinach. Szkice do historii KL Stutthof - Aussenlager Pölitz, Szczecin 2009.

30 There is already extensive literature on camp medicine and hospitality. See more e.g.: M. Ciesielska, Szpital obozowy dla kobiet w KL Auschwitz-Birkenau (1942-1945), Warzsawa 2015; W. Fejkel, O stużbie zdrowia w obozie koncentracyjnym, "Przegląd Lekarski" 1961, no. 1; idem, Więźniarski szpital w KL Auschwitz, Oświęcim 1994; E. Klee, Medycyna III Rzeszy i jej ofiary, expl. E. Kalinowska-Styczeń, Kraków 2011; S. Kłodziński, Zbrodnicze doświadczenia farmakologiczne na więźniach obozu koncentracyjnego w Oświęcimiu, "Przegląd Lekarski" 1965, no. 1; J. Kowalczykowa, Choroba głodowa w obozie koncentracyjnym w Oświęcimiu, "Przegląd Lekarski" 1961, no. 1; A. Makowski, Organizacja, rozwój i działalność szpitala więźniarskiego w Monowicach (KL Auschwitz III), "Zeszyty Oświęcimskie" 1974, no. 15; Medycyna w cieniu nazizmu, ed. M. Musielak, K.B. Głodowska, Poznań 2015; J. Mikulski, Medycyna hitlerowska w stużbie III Rzeszy, Warszawa 1981; K. Okoniewska, Zbrodniczy medycy. Lekarze Auschwitz, Łódź 2017; J. Olbrycht, Sprawy zdrowotne w obozie koncentracyjnym w Oświęcimiu, "Przegląd Lekarski" 1962, no. 1; S. Sterkowicz, Zbrodnie hitlerowskiej medycyny, Warszawa 1987; I. Strzelecka, Eksterminacyjna funkcja szpitali obozowych w KL Auschwitz, "Przegląd Lekarski" 1990, no. 1; eadem, Oddział kobiecy w męskim obozie macierzystym, "Zeszyty Oświęcimskie" 1993, no. 20; eadem, Rozwój szpitali obozowych w Oświęcimiu-Brzezince, "Przegląd Lekarski" 1984, no. 1; eadem, Medical crimes. Medical experiments in Auschwitz, Oświęcim 2008; eadem, Medical crimes. The hospitals in Auschwitz, Oświęcim 2008; Z. Ryn, Medycyna obozów koncentracyjnych i jenieckich w piśmiennictwie zachodnim, „Przegląd Lekarski" 1985, no. 42; idem, Death and Dying in the Concentration Camp, "American Journal of Social Psychiatry" 1983, no. 3; Z. Ryn, S. Kłodziński, Głód w obozie koncentracyjnym, "Przegląd Lekarski" 1984, no. 41; S. Sterkowicz, Zbrodnie hitlerowskiej medycyny, Warszawa 1990.

31 B. Waluk, Obozy pracy przymusowej i karne obozy pracy w Policach k. Szczecina 19391945, [in:] Z problematyki medycyny w hitlerowskich obozach koncentracyjnych, Gdańsk 1971; idem, Obóz koncentracyjny w Policach-Mścięcinie k. Szczecina (filia obozu koncentracyjnego Stutthof) 27 VI 1944-26 IV 1945 r., [in:] Z problematyki medycyny...

32 M. Lambert, Warunki sanitarno-higieniczne w obozach pracy przymusowej $w$ rejonie Szczecina w latach II wojny światowej, "Przegląd Zachodniopomorski" 3, 1972. Cf also: Archives of the

Studia nad Autorytaryzmem i Totalitaryzmem 42, nr 1, 2020

C for this edition by CNS 
remains. It is true that this issue featured in works on Konzentrationslager Stutthof but only on the margins of wider considerations. ${ }^{33}$

Preserved archives on camps located in the former Pomeranian Province are fragmented. They only allow for a limited and fragmented analysis of the policy of Hitler's regime towards prisoners from particular areas. This article is mostly based on archival materials of the Institute of National Remembrance, especially the Archives of the Branch Office of the Commission For the Prosecution of Crimes Against The Polish Nation of the Institute of National Remembrance in Szczecin (previously files of the District Commission For the Prosecution of Hitler's Crimes in Szczecin). These mostly included minutes of witnesses' testimonies and accounts (by former prisoners) as well as the camp's official documentation. The undoubtful advantage of this documentation is its direct, evidential nature and being produced "first hand". It is, however, obvious that we should remain aware of its subjectivity. The world it presents is filtered through emotional, sometimes very personal, neurotic experiences of being held in a "death camp". This, however, does not change the fact that such type of material, although with some limitations, is a valuable account of past times. These materials form an irreplaceable as well as interesting source for the researched issue. Of outstanding value are also collections of documents (records) deposited in the Archives of the Stutthof Museum, especially personal files, registries, record files, prisoners' transport lists, and camp hospital files.

\section{The establishment of KL Stutthof in Police}

In Hitler's policy, concentration camps performed two essential functions. Firstly they served as a place of physical extermination and acts of terror towards the population of conquered countries. Then, as outlined in 1942, they turned from a "place of isolation" into large units of organisation of the entire system that consisted of a central unit called a "camp for protective custody" (Schutzhaftlager) and the so-called "external camps" (Aussenlager), "Kommandos" that were officially treated as "labour camps" (Arbeitslager). They formed the

Branch Office of the Commission For the Prosecution of Crimes Against The Polish Nation of the Institute of National Remembrance in Szczecin (further: AIPN Sz) 5/128, M. Lambert, Niektóre problemy medyczne obozu koncentracyjnego w Mścięcinie, file no. 5/128, mps.

33 Especially noteworthy is also the trailblazing research on camp hospitals, and medical and issues issues in KL Stutthof by Mirosław Gliński, Miron Kłusak, and Bogdan Siniecki. Cf. M. Gliński, Organizacja i obsada personalna...; idem, Obsada szpitala obozowego w Stutthofie, "Przegląd Lekarski” 1971, no. 1; M. Kłusak, Zachorowalność więźniów, jej przyczyny i lecznictwo w obozie koncentracyjnym Stutthof w latach 1939-1945, "Stutthof. Zeszyty Muzeum" 1976, no. 1; B. Siniecki, Z historii szpitala obozowego w Sztutthofie, "Przegląd Lekarski" 1975, no. 1 (reprinted in: Okupacja i medycyna. Trzeci wybór artykułów z "Przeglądu Lekarskiego" - Oświęcim z lat 1963-1976, Warszawa 1977).

Studia nad Autorytaryzmem i Totalitaryzmem 42, nr 1, 2020

(C) for this edition by CNS 
category of sub-camps that in the organisational makeup came under the command of the central camp. ${ }^{34}$

From then on, maximization of the use of labour for the needs of war industry became the additional function of concentration camps. Alongside serving as centres of extermination, the camps also started to play a role in multiple sectors of the Third Reich economy, including the arms industry. In a nutshell, they were a source of cheap forced labour. ${ }^{35}$ This function was performed by the sub-camps of central camps, whose development accelerated largely in the second half of 1944. The entire system was changing so dynamically that even the SS - WVHA (SS - Wirtschafts - und Verwaltungshauptamt, i.e. SS Main Economic and Administrative Office) lost count. According to its officials, 500 sub-camps existed in January 1945. However, the real number was slightly higher and amounted to 560, while some researchers claim it could have reached even up to $1202 .{ }^{36}$ All of them were administratively subordinated to the SS - WVHA. The Stutthof concentration camp had 71 sub-camps, set up between 2nd September 1939 and 9th May 1945. In total they held 110,000 prisoners. ${ }^{37}$

34 E. Georg, Die wirtschaftlichen Unternehmungen der SS, "Schriftenreihe der Vierteljahrshefte für Zeitgeschichte" 1963, no. 7, pp. 41-65; E. Kogon, Der SS-Staat. Das System der deutschen Konzentrationslager, Frankfurt am Main 1965, p. 269; M. Orski, Filie obozu koncentracyjnego Stutthof w latach 1939-1945, Gdańsk 2004, p. 69. Also more: N. Waxchsmann, Historia nazistowskich obozów koncentracyjnych, Warzsawa 2016; K. Orth, Die Konzentrationslager-SS...; idem, Die Konzentrationslager-SS. Soziokulturelle...; J. Kosiński, Niemieckie obozy koncentracyjne i ich filie, ed. W. Sobczyk, Stephanskirchen 1999; U. Herbert, K. Orth, Ch. Dieckmann, Die nationalsozialistischen Konzentrationslager: Entwicklung und Struktur, vol. 1, Göttingen 1998; W. Benz, B. Distel, op. cit.

35 J. Matynia, Literatura i materiaty źródłowe o filiach obozu koncentracyjnego Stutthof, "Gdańskie Zeszyty Humanistyczne. Seria Pomorzoznawcza” 1969, no. 18, pp. 191-205; A.J. Kamiński, Hitlerowskie obozy koncentracyjne i ośrodki masowej zagłady w polityce imperializmu niemieckiego, Poznań 1964, pp. 121-174, 152-154.

${ }^{36}$ N. Wachsmann, Historia nazistowskich obozów koncentracyjnych, trans. M. Antosiewicz, Warszawa 2016, pp. 511-528; A. Lasik, Sztafety ochronne w systemie niemeckich obozów koncntracyjnych, Oświęcim 2007. The head administrator of concentration camps was Oswald Pohl.

37 G. Schwarz, Die Nationalsozialistischen Lager, Frankfurt am Main 1997, pp. 87-235. See also subject literature on (KL) Stutthof: M. Orski, Niewolnicza praca więźniów obozu koncentracyjnego Stutthof 1939-1945, Gdańsk 1999; idem, Filie obozu koncentracyjnego Stutthof w latach 1939-1945, Gdańsk 2004; idem, Przedsiębiorstwa SS i firmy prywatne - najemcy sity roboczej obozu koncentracyjnego Stutthof w latach 1939-1945, Gdańsk 2001; idem, Organisation und Ordnungsprinzipien des Lagers Stutthof, [in:] Die nationalsozialistischen Konzentrationslager..., pp. 285-308; K. Dunin-Wąsowicz, Obóz koncetracyjny Stutthof, Gdynia 1966; idem, Stutthof...; idem, Stutthof. Ze wspomnień więźnia...; K. Ciechanowski et al., op. cit.; M. Gliński, Organizacja obozu koncentracyjnego Stutthof (1 września 1939-9 maja 1945), "Zeszyty Muzeum Stutthof" 1979, no. 3; J. Grabowska, H. Kuhn, K.L. Stutthof - Ein historischer Abriss, Bremen 1993; J. Grabowska, op. cit.; eadem, Marsz śmierci. Ewakuacja piesza więźniów KL Stutthof i jego podobozów 25 stycznia-3 maja 1945, Gdańsk 1992; H. Schmidt, Die Gerettete Freude. Eines jungen Menschen Zeit 1925-1945, Potsdam 2001 (primarily pp. 272-365); R. Alton, op. cit.; D. Drywa, Zagłada Ży-

Studia nad Autorytaryzmem i Totalitaryzmem 42, nr 1, 2020

(C) for this edition by CNS 
The Pomeranian Province played a vital part in the organisation and policy of the Third Reich. In economic terms, it was an agrarian area that provided food supplies to the population at the time of war as well as peace. It was also significant from a military point of view as a base for military operation in the East. The construction of huge defence fortifications - the so-called Pomeranian Wall also began in the province in the 1930s. ${ }^{38}$

The specific character of that area made a significant impact on forced labour camps that were established there. Their prisoners, already held there since 1942, were treated as a source of cheap labour and exploited in various sectors of the economy of the Third Reich, especially in agriculture and the arms industry. For example, during the Second World War 225,190 forced labourers ${ }^{39}$ and 81,316 war prisoners, ${ }^{40}$ including 116,000 Polish, 69,000 Soviet and 21,000 French nationals ${ }^{41}$ were subject to forced labour in the Pomeranian Province. ${ }^{42}$

dów w obozie koncentracyjnym Stutthof (wrzesień 1939-maj 1945), Gdańsk 2001; E. Grot, op. cit.; M. Owsiński, Polscy więźniowie polityczni w obozie Stutthof 1939-1945, Toruń 2001.

38 The Pomeranian Wall - a part of a system of fortifications at the eastern border of the Third Reich. Cf. A. Jasiński, Przełamanie Wału Pomorskiego, Warszawa 1958; A. Toczewski, Bitwa o Odrę w 1945 roku, Zielona Góra 2010; J. Miniewicz, B. Perzyk, Wat Pomorski, Warszawa 1997; A. Czerkawski, M. Dunin-Wąsowicz, Wat Pomorski, Warszawa 1970; E. Kospath-Pomorski, Wat Pomorski 1945, Warszawa 1995; K. Sobczak, Bitwa o Wat Pomorski: spojrzenie z perspektywy pótwiecza, "Kronika Wielkopolska" 1995, no. 1, pp. 19-35.

39 Numbers as for 30th September 1944, Arbeitseinsatz im Deutschen Reich, no. 11/12 on the 30 December (1944).

40 Numbers as for 15th February 1944, Arbeitseinsatz im Deutschen Reich, no. 4/5 on 31st May (1944).

41 State Archives in Szczecin (further: APS), Bogdan Frankiewicz's Collection, file no. 138, System i hitlerowskich obozów pracy przymusowej i obozów jenieckich na Pomorzu Zachodnim w latach 1939-1945 [The system and location of Nazi forced labour camps and prisoners-of-war camps in Western Pomerania between 1939 and 1945], unnumbered cards.

42 The basic types of camps that officially existed in the Pomeranian province included: 1) collective accommodation camps housing a large number of labourers working in different plants. They were also known as foreigners' camps. Special regulations in those camps limited personal freedoms of inmates. 2) Plant or company camps sometimes also based on nationality, e.g. Polenlager, Franzosenlager. They housed workers only from a particular plant or company. Personal freedoms were restricted in those camps and they were under the supervision of police authorities of the area. 3) Temporary or separation camps. They were meant for workers arriving in transports before they were moved to their assigned camps. Prisoners stayed there for a short time, a few days. 4) Motorway construction camps were located alongside the route from Szczecin to Bytów. Those were maximum security camps modelled on military camps. 5) Camps on ships 6) Prisoner-of-war camps: oflags, stalags, arbeitskommands. 7) Educational labour camps or penal camps, 8) Subcamps of concentration camps. 9) Prisoner-of-war camps. 10) accommodation camps. Cf. APS, Bogdan Frankiewicz's Collection, file no. 138, System i hitlerowskich obozów pracy przymusowej i obozów jenieckich na Pomorzu Zachodnim w latach 1939-1945 [The system and location of Nazi forced labour camps and prisoners-of-war camps in Western Pomerania between 1939 and 1945], unnumbered cards.

Studia nad Autorytaryzmem i Totalitaryzmem 42, nr 1, 2020

(C) for this edition by CNS 
The way the sub-camp in Pölitz operated depended on the requirements of the German arms industry. It was created to provide cheap labour for a synthetic fuel factory (Chemische Werke Hydropetroleum Industrie Gesellschaft), a strategic plant for the German war industry. ${ }^{43}$ Prisoners of concentration camps were never in good health, but health problems of prisoners in Pölitz were caused not only by poor sanitation, hygiene, and living conditions, but also by harsh working conditions in the factory. The operation of Aussenlager Pölitz could also be considered in the context of the so-called small camps. In many cases, researchers in the field of healthcare in concentration camps focus their attention on central camps and hence miss this aspect in the sub-camp. This aspect, however, is vital because in many camps only some prisoners remained in the "parent" units, whereas other, more or less numerous groups were moved to sub-camps located outside the central unit. ${ }^{44}$

The central concentration camp in Stutthof, a sub-camp of which was located in Pölitz, was set up as soon as 2nd September 1939. Its parent unit was established in the territory of the former Free City of Danzig. Initially, this was a camp only for Polish civilian prisoners. The first prisoners of other nationalities, e.g. Russians and Germans, arrived in 1941. In 1942 Stutthof became a state concentration camp. ${ }^{45}$

The sub-camps of Konzentrationslager Stutthof maintained the same number and colour system of camp badges ${ }^{46}$ as the one characteristic for the central camp.

43 Chemische Werke Hydropetroleum Industrie Gesellschaft was one of 12 plants of IG Farben Industrie that manufactured synthetic fuel (as well as oils, lubricants, and by-products such as soot and tar) for the Luftwaffe, Kriegsmarine, and tanks and armed vehicles of Wehrmacht. P. Fiuk, Zarys historii Polic i dawnej fabryki benzyny syntetycznej - Hydrierwerke Politz - Aktiengesellschaft, "Przestrzeń i Forma" 2007, no. 5, pp. 17-26; cf. APS, Bogdan Frankiewicz's Collection, file no. 305, Hitlerowski system obozowy w Policach, cards 128-133; ibidem, file no. 116, Hydrierwerke Politz, cards 6-10.

44 M.E. Jezierska, Zagadnienie małych obozów, "Przegląd Lekarski” 1967, no. 1, pp. 127-128.

45 The decision to recognise Stutthof as a concentration camp was taken on 7th January, 1942, a few weeks after Heinrich Himmler's visit to Stutthof on 23rd November, 1941. K. Dunin-Wąsowicz, Police, Warszawa 1974, pp. 44-78, here: pp. 47-48; idem, Stutthof..., pp. 38, 39-69; M. Orski, Obywatele francuscy w obozie koncentracyjnym..., pp. 7-24; K. Ciechanowski, Geneza obozu w Stutthof - obozy internowania na Pomorzu Gdańskim od września 1939 r. do marca 1940 r., [in:] K. Ciechanowski et al., op. cit., pp. 51-78.

46 Concentration camp badge - a triangle sewn on prisoners' clothes with a letter indicating the nationality of the prisoners. It was a system of identification of prisoners initially introduced in KL Dachau and subsequently adopted in other camps. The red colour indicated a political prisoner and a representative of a "lower race", like Poles, Russians, and Jews. The green colour was reserved for thieves, fraudsters, and forgers. Most of them were German citizens, often serving as prisoner functionaries. A black triangle was attributed to other social outsiders, such as prostitutes, beggars, and drifters. Whereas purple was attributed to the Bible Researchers, and pink indicated homosexual prisoners. Jewish nationality of prisoners was marked by a six-pointed geometric star figure made of two yellow triangles. Cf. A Chyrek, Numeracja i sposób oznaczania więźniów w obozie Stutthof, "Pamięć i Sprawiedliwość" 2006, no. 2 (10), pp. 183-208.

Studia nad Autorytaryzmem i Totalitaryzmem 42, nr 1, 2020

(C) for this edition by CNS 
Sub-camps were divided into two categories: external camps with and without Jewish prisoners. A more precise typology may also be drawn based on the nature and objectives of particular camps. The first involved rather small units organised to carry out a particular job in a particular place, for example Nowy Port (Neufahrwasser). Next, there were camps for prisoners who had already served their sentence in Stutthof and for political prisoners, for example in Potulice (Potulitz). The third category included the main sub-camps of Stutthof, established between the summer and autumn of 1944. There was also a fourth category for Jews. They were set up in the summer and autumn of 1944, e.g. Sępopol (Schippenbeil). A large number of Stutthof sub-camps meant that at the end of January 1945 the total number of prisoners held there numbered 24,000, including 17,000 women and 7,000 men, whereas the central camp held 23,000 people (12,000 women and 11,000 men). A confrontation of these numbers gives a wider picture of how expansive the system of Stutthof sub-camps was. ${ }^{47}$

The sub-camp in Pölitz fell under the category of main sub-camps without Jewish prisoners. It was one of many dozens of such camps on the territory of Poland. ${ }^{48}$ Their organisation was modelled on the central camp and their task was to provide cheap labour to the nearby synthetic fuel factory - Chemische Werke Hydropetroleum Industrie Gesellschaft (Hydrierwerke Pölitz). It was these chemical plants that took the initiative to create a sub-camp of Stutthof in Pölitz. The technical plans for the camp were developed by the management of the company. ${ }^{49}$ It is worth adding that there were seven different camps within the industrial premises in Pölitz, including four collective accommodation camps (Gemeinschaftslager)

47 K. Dunin-Wąsowicz, Police..., pp. 50-52; M. Orski, Filie..., pp. 10-15, 239-246; M. Gliński, Podobozy obozu Stutthof..., pp. 502-506; idem, Podobozy $i$ większe komanda..., pp. 245-248.

48 In the course of its existence, i.e. from 2nd September 1939 to 9th May 1945, the Stutthof camp had 71 sub-camps, one of them located in Pölitz. Each sub-camp was modelled on the parent central camp. Among the main reasons behind creating sub-camps was first of all economic benefits from slave labour of prisoners and overpopulation of the central camp. The sub-camp's staff most often consisted of a commandant and two or three SS soldiers who also performed administrate functions. Guards were mostly recruited among prisoners who wanted to improve their living conditions in the camp. Cf. M. Gliński, Podobozy i większe komanda ..., pp. 290-295 and ext.: K. Ciechanowski et al., op. cit.; M. Gliński, Organisation und Ordnungsprinzipien des Lagers Stutthof, [in:] Die nationalsozialistischen Konzentrationslager..., pp. 285-308; D. Blatman, op. cit., pp. 111-112; idem, Les marches de la mort: la dernière étape du génocide nazi: été 1944-printemps 1945, Paris 2009, pp. 127-131; P. Matussek, op. cit., pp. 19-20; M. Przyłucka, Praca więźniów w obozie koncentracyjnym Stutthof, "Stutthof. Zeszyty Muzeum" 1977, no. 2; H. Schmidt, Die Gerettete Freude. Eines jungen Menschen Zeit 1925-1945, Potsdam-Babelsberg 2001, pp. 272-365; M. Jezierska, Obozy w Policach ..., pp. 84-85; B. Waluk, Obozy pracy..., pp. 179-184; B. Frankiewicz, Hitlerowskie obozy...; idem, Obozy hitlerowskie na ziemi szczecińskiej...

49 APS, Acts of the city of Szczecin, section no. 1488a. Map title: Entwässerung des $K L$ Lagers in Messenthin zum Kriecklands - Bach. Bau [Drainage of the KL Camp in Messenthin to Kriecklands - Construction Plan], no. 903.

Studia nad Autorytaryzmem i Totalitaryzmem 42, nr 1, 2020

(C) for this edition by CNS 
subordinated to the police board in Szczecin, two maximum security penal camps, and a sub-camp of Stutthof. ${ }^{50}$

The concentration camp in Pölitz was set up by a special order issued by the Stutthof Concentration Camp Kommandantur on 25th June 1944. ${ }^{51}$ The sub-camp changed its location twice. At first, it operated as Pölitz bei Stettin - Lager Hägerwelle. From the prisoners' point of view it was a seasonal camp in summer ${ }^{52}$. A new order from the Kommandantur, which came on 2nd November that year, gave the Pölitz sub-camp a new address: Pölitz bei Stettin Messenthiner Waldhalle ${ }^{53}$. In prisoners' testimonies and accounts it was treated as a seasonal camp in winter. Since the day of its creation it was believed to be one of the hardest camps.

\section{Organisation and planning of Aussenlager Pölitz}

The position of the camp commander was held by SS Oberscharführer Hans Kuhlmann (25th June-5th August 1944), SS-Hauptsturmführer Ernst Sette (until

50 B. Frankiewicz, Praca przymusowa na Pomorzu Zachodnim, w latach II wojny światowej, Poznań 1969, pp. 95-96. Harsh living conditions made prisoners try to escape. Firstly, 11 prisoners tried to escape at the end of July 1944. In September, 5 prionsers managed to escape. There were 10 more documented attempts by the end of 1944 that onvolved about 20 prisoners. The last succesful attempt took place in February 1945. There were definitly more attempts but they are not documented. Cf. M. Orski, Filie..., pp. 311-312; M. Jezierska, Ucieczki z obozu..., p. 201; K. Dunin-Wąsowicz, Ruch oporu w hitlerowskich obozach koncetracyjnych 1933-1945, Warszawa 1983, p. 207.

51 Archives of Stutthof Museum (further: AMS), file no. I IB-3, Sonderbefehl über die Eintichtung des Aussenlagers Pöliz b. Stettin. The order to establish the camp issued on 25th June 1944.

52 The first 600-strong group pf prisoners arrived at Ausselager Politz in June 1944. They were located in the temporary summer camp next to the forced labour camp in Hägerwelle. They were transferred to the summer camp in Mścięcino (Messenthin) in Autumn 1944. Cf. M. Orski, Filie obozu koncentracyjnego..., p. 307; B. Waluk, Obozy pracy..., pp. 177-178; M. Jezierska, Obozy w Policach..., pp. 84-85; K. Dunin-Wąsowicz, Police..., p. 52; J. Nowicki, Od Stutthofu do Sandbostel, "Przegląd Lekarski" 1968, no. 1, pp. 158-159. One of the first transports to Ausselager Politz came from Pawiak prison. See more: A. Kłys, Z Pawiaka do Polic. Więźniowie z Pawiaka w obozie koncentracyjnym Stutthof i podobozie Police k/Szczecina, "Niepodległość i Pamięć"..., pp. 41-86; idem, Z Pawiaka do Polic. Więźniowie z Pawiaka w obozie koncentracyjnym Stutthof i podobozie Police k/Szczecina, [in:] Historia — ludzie - pamięć..., pp. 249-277. The majority of prisoners of Ausselager Politz came from Western Pomerania, from Stutthof and Buchenwald. Cf. B. Frankiewicz, Obozy hitlerowskie na Pomorzu Zachodnim..., p. 59.

53 Archives of the Branch Office of the Commission For the Prosecution of Crimes Against The Polish Nation of the Institute of National Remembrance in Szczecin (further: AIPN Sz, OKBZH) with a file no. S/15/68/OKS, Prosecutor's Main Acts (Akta Główne Prokuratora, AGP), $W$ sprawie zbrodni hitlerowskich popetnianych wobec robotników przymusowych i jeńców wojennych osadzonych w obozach karnych i pracy przymusowej na terenie Polic i okolicznych miejscowości, Postanowienie o zawieszeniu i częściowym umorzeniu postępowania karnego [Szczecin 15 August 1978], vol. 8, card 118; AIPN Sz, OKBZH, file no. S/15/68/OKS, card 180, Zamiejscowy Obóz Pracy Police k/Szczecina, "Sonderlager Pölitz bei Stettin" 1939-1977.

Studia nad Autorytaryzmem i Totalitaryzmem 42, nr 1, 2020

(C) for this edition by CNS 
18th August 1944) and SS-Untersturmführer Kurt Volkmann ${ }^{54}$ respectively. The 50-strong camp crew consisted of SS-men, Wehrmacht soldiers and Ukrainians serving in auxiliary units. In the supervisory section made up of prisoners the position of Lagerältester I (camp senior) was held by Wacław Kozłowski ${ }^{55}$ and his deputy was Erich Schamp (Lagerältester II). ${ }^{56}$

The camp itself comprised an administrative unit with utility barracks, Kommandentur, SS soldiers' rooms and camp administration offices, as well as a unit for prisoners, and a medical, sanitation, and hygiene unit (outdoor toilets, washroom, and delousing rooms). All sanitary facilities were provisional. There were open-air washrooms (washbasins with trough-type drains and cold water taps installed above). ${ }^{57}$ Not all prisoners received soap. It was only given to prisoner functionaries. Regular prisoners used the delousing rooms within the premises of the camp. The structure of the camp also comprised a kitchen, a food warehouse (a so-called bread warehouse), and barrack huts where prisoners deposited their clothes. In the Pölitz sub-camp, there was also a separate space for men and women. Some unverified sources claim it consisted of four barrack huts and was a sub-camp of the Ravensbrück camp. ${ }^{58}$

54 Cf. M. Gliński, Załoga obozu koncentracyjnego Stutthof (1 IX 1939-9 V 1945), part II. K-Q, "Stutthof. Zeszyty Muzeum” 1985, no. 6, p. 104; idem, Załoga obozu koncentracyjnego Stutthof (1 IX 1939-9 V 1945), part III. R-Z (updated), "Stutthof. Zeszyty Muzeum” 1987, no. 7, p. 216, 224.

55 K. Dunin-Wąsowicz wrote: "Kozłowski was a trained butcher and — surprisingly — loved music. He could spend hours sitting down and listening to playing the accordion. Then suddenly he could jump to his legs and for any triviality, such as a loose button, he smashed the poor prisoner's head or pushed him to the ground and jumped on his chest till he broke his victims' ribs", idem, Stutthof. Ze wspomnień więźnia..., p. 19. J. Jagodziński's account of events corresponds with that statement: "When returning to the block, we learnt that Wacław Kozłowski, an infamous murder of prisoners, travelled with the transport. [...] It became clear that the worst sort of kapos, hilfskapos and the so-called 'old numbers' was coming with the transport. [...] Following the morning drill $[\ldots]$ an inspection and segregation started again — it was meant to be the final one. [...] Kozłowski turned up shortly. On his sleeve he wore a new Lagerältester I armband. He was visibly proud of his nomination - he moved his arm in such a way that everybody could see what his new function was", idem, op. cit., pp. 35-37. Kozłowski was sentenced to death in 1946 at the Regional Court in Gdańsk in the first trial of the JK Stutthof crew (25th April-1st June). See also: M. Owsiński, Sprawca w propagandzie medialnej na przykładzie pierwszego procesu stutthofskiego, kwiecieńmaj 1946, [in:] Jak rodzi się zło? Sprawcy, wykonawcy, pomocnicy, ed. A. Bartuś, Oświęcim 2018, pp. 215-246; W. Kaniewski, Odpowiedzialność karna sprawców zbrodni popetnionych w Konzentrationslager Stutthof, "Pamięć i Sprawiedliwość" 40, 1997/1998, pp. 162-172.

56 Erich Schamp — born 13.04.1901, KL Stutthof prisoner AMS, Księga ewidencyjna, file no. I-IIE-6-56.

57 Antoni (Anton) Budzejko (Brudziejko) — DOB 18.04.1918, KL Stutthof prisoner no. 18175; AMS, Akta osobowe, file no. I-III-41404; AMS, Wykazy w blokach, file no. I-IIIB-8; AMS, Księga ewidencyjna, file no. I-IIE-6; AMS, Szpital obozowy, file no. I-VB-22; AGP, $W$ sprawie zbrodni hitlerowskich..., vol. 8, card 168 - The minutes of the testimony of a witness Józef Jagodziński.

58 K. Dunin-Wąsowicz, Police..., pp. 56-57.

Studia nad Autorytaryzmem i Totalitaryzmem 42, nr 1, 2020

(C) for this edition by CNS 
The camp in Pölitz was surrounded by a fence. Initially, there was only one barbed-wire fence, then a second one was added. Watchtowers with guards equipped with machine guns were located in the corners (in prisoners' jargon they were called "zwyżki" or "bocian"). A vast majority of staff was stationed in the camp, but there were also some coming from outside. According to former prisoners' testimonies, the camp held a few thousand prisoners of various nationalities. Among them were Poles, Russians, Lithuanians, Latvians, Yugoslavs, Serbs, Greeks, Frenchmen, Germans, and a small number of Italians. ${ }^{59}$ At the end of the camp's existence, the Jewish population was also kept in a separate part of the camp.

The prisoners' unit was the largest part of the camp. In its central part there was a drill ground with gallows located in the corner. Prisoners were housed in 32 barrack huts (blocks) erected between 1944 and 1945. Four of them were for females only. ${ }^{60}$ Each of them was "inhabited" by 100 to 200 people. Barracks were densely populated. Each consisted of the so-called "sztuby" (chamber, part of a block) where prisoners slept in bunk beds (in prisoners' jargon known as "kojki"). These were most often wooden beds measuring $190 \mathrm{~cm}$ in length, $70 \mathrm{~cm}$ in width and 200 in height. Blocks no. 1 and 2 had no windows. The entrance was located opposite. Three-tier 'berths' stood on one side of the barrack. On the narrower side there were tables. There was only hard earthen floor. A makeshift latrine was a few metres away from a watchtower. ${ }^{61}$ Prisoners were divided into groups and commandos. The first division referred to barracks allocated to prisoners, whereas the other was based on work allocation (Kommandos - columns, brigade, working group). Brigades usually consisted of $40-50$ people. $^{62}$

59 Establishing the real number of people held in the camp is difficult. The source literature gives various estimates. It indicated there were from 800 to 2,800 prisoners in the camp in August 1944. According to other figures, the number could have been as large as 9,000. The difference results from taking into account not only the prisoners of KL Stutthof themselves but also groups held in the neighbourhood. On evacuation day, that is 23rd April 1945, the number of prisoners was estimated at 2,000. The prisoners themselves, however, estimated the number to be a few hundred people. Cf. B. Frankiewicz, Praca przymusowa..., pp. 95-107, here: p. 106; M. Orski, Niewolnicza praca więźniów obozu koncentracyjnego Stutthof w latach 1939-1945, Gdańsk 1999, p. 309 ff.; idem, Filie..., p. 308; M. Jezierska, Obozy w Policach ..., pp. 85-90. J. Jagodziński, op. cit., p. 10. In his testimonies, Józef Jagodziński — who has already been mentioned — indicates that the number of prisoners in Pölitz amounted to about 6,000, whereas on evacuation day there were fewer than 400 prisoners. Cf. Józef Jagodziński — DOB 11. 05.1905, KL Stutthof prisoner no. 35790; AMS, Księga ewidencyjna, file no. I-IIE-6; AIPN Sz, OKBZH, file no. S/15/68/OKS, AGP, W sprawie zbrodni hitlerowskich..., vol. 6, card 60-69 - The minutes of the testimony of a witness Józef Jagodziński.

60 According to B. Frankiewicz there could be about 600 women in the barracks of Ausselager Politz who came from Frauen-Konzentrationslager Ravensbrück. Cf. APS, Bogdan Frankiewicz's Collection, file no. 305, Hitlerowski system obozowy w Policach, card 151.

61 J. Nowicki, op. cit., p. 159.

62 M. Orski, Filie..., p. 308; J. Jagodziński, Bunkry na ruinach ..., p. 26; B. Frankiewicz, Praca przymusowa..., pp. 105-106; idem, Obozy hitlerowskie na Pomorzu Zachodnim..., p. 59; cf. APS, Bogdan Frankiewicz's Collection, file NO. 305, Hitlerowski system obozowy w Policach, card 151.

Studia nad Autorytaryzmem i Totalitaryzmem 42, nr 1, 2020

(C) for this edition by CNS 
The day at the camp started at 5am with a morning drill. ${ }^{63}$ There were usually two or three drills in the camp. Prisoners gathered at the central ground. The attendance was checked and then they went for breakfast. This was one of two meals prisoners received during the day. Food was rather poor. Prisoners received a piece of bread with a bit of sausage and a small amount of margarine. A packet of margarine was usually divided into 16 portions, and when the camp was short of food - even into 24 portions. These already poor food rations were further diminished by a kapo (leader of a Kommando of workers) who divided it first among his helpers (hilfskapo, unterkapo) and the so-called "old numbers" (prisoners who had been held in the camp for the longest time). As a result, food rations that regular prisoners finally received were even smaller than specified in the camp regulations. For lunch there was usually 0.5 litres of watery soup with a small amount of potatoes, cabbage or swede. ${ }^{64}$ It was the only warm meal during the day. These small food rations caused severe famine in the camp. The difficult situation in the camp resulted from both inhuman living conditions and direct extermination. Prisoners recall it in the following way:

meals $[\ldots]$ were wholly insufficient. So that prisoners sometimes ate bark, clay and even human excrements covered in leaves. Such a diet led to huge mortality in the camp. The official records show the number of prisoners fluctuated around 6,000, out of which about 5,400 died of hunger, exhaustion or illness, or were murdered. ${ }^{65}$

Prisoners did not receive fully nourishing meals. Most often the food was low on calories and strictly rationed. The only nutritious food they received was bread.

Early in the morning, after the morning drill and breakfast prisoners were delegated to do various tasks, such as construction, electric, transport, or cleaning works. They worked on average 12 hours a day and did an additional 4 hours of work in the camp.

\section{Medical care in Aussenlager Pölitz}

Some larger sub-camps had medical facilities. In the structure of the central camp it was included in Department V, which covered medical services. The duties of the head doctor included taking care of the sanitary conditions of the whole

63 Following the morning alarm, the block supervisors directed prisoners to a makeshift wash-stand under a "clear blue sky". Prisoners did not get any soap and fought over the access to pipes with fresh water. Hence it happened that some prisoners were only able to have a wash after work. Cf. J. Nowicki, op. cit., p. 159.

64 J. Jagodziński, Bunkry na ruinach..., pp. 41-71, here: p. 43.

65 Józef Jagodziński, DOB 11. 05.1905, KL Stutthof prisoner no. 35790; AGP, $W$ sprawie zbrodni hitlerowskich..., vol. 6, card 68 - The minutes of the hearing of witness Eugeniusz Bojko.

Studia nad Autorytaryzmem i Totalitaryzmem 42, nr 1, 2020

(C) for this edition by CNS 
camp, the health of prisoners as well as the staff, equipping the camp with medical devices and medicines, and selecting the prisoners. ${ }^{66}$

According to prisoner accounts, the camp doctor was a German called Karl Heyman Heydecke (documents also show the spelling Heidecke). ${ }^{67} \mathrm{He}$ was, however, not at all interested in the camp hospital, referred to in the local jargon as "rewir". ${ }^{68}$ Often did he treat sick prisoners like malingerers and did not provide medical assistance. He spent most of his time in Szczecin and his role in the camp was limited to signing documents that allowed to produce death certificates.

Medical facilities in Pölitz were organised in a similar way to those in other sub-camps. It included some basic equipment such as tables, beds, and cabinets. According to witness accounts "to the left from the camp entrance there was a barrack with a sick room, first-aid room, and camp doctor's - dr. Bolesław Kaczynski's - room". ${ }^{69}$ The "rewir" in Pölitz consisted of internal diseases, surgical, and tuberculosis wards. The first was supervised by Tadeusz Kamiński, ${ }^{70}$

66 E. Ferenc, Budowa i rozbudowa obozu koncentracyjnego Stutthof (2.09.1939-31.12.1944), [in:] K. Ciechanowski et al., op. cit., pp. 494-495; M. Lambert, Niektóre problemy medyczne...; idem, Warunki sanitarno-higieniczne..., pp. 151-156.

67 His surname does not appear in the list of the staff. Cf. M. Gliński, Załoga obozu koncentracyjnego Stutthof (1 IX. 1939-9 V 1945), part I. A-J, "Stutthof. Zeszyty Muzeum" 1984, no. 5, pp. 187-216; idem, Załoga obozu koncentracyjnego Stutthof (1 IX 1939-9 V 1945), part II, p. 104 (there: Hans Kuhlmann — born on December 3, 1906. In 1941, a member of the 2nd Guard Company in KL Stutthof, then - from November 9th 1942 to June 20th 1944 — a sub-camp commander in Nadbórze/Hopehill, a sub-camp commander in Police, a sub-camp commander in Gdynia - 16th October-9th December 1944, then again in KL Stutthof); idem, Załoga obozu koncentracyjnego Stutthof, part III, p. 216. (there: Ernst Sette - deputy head of Department III in the Staff of the Stutthof Headquarters - from June 29th 1944 to April 5th 1945).

68 "Rewir" (from German Krankenrevier) — camp hospital. It was divided into various blocks and rooms, each of them with their own name. It was included in the structure of the camp: quarantine - a prison block where newcomers were housed temporarily before being moved to blocks for prisoners Also obligatory for convalescents from typhus. It served also as a sick room for patients recovering from infectious diseases. The blocks in the "rewir" and numbers assigned to them depended on the category of illness. For example, Block 12 was a cellblock at Brzezinka's camp hospital for female prisoners suffering from Typhus, whereas Block 10 was Karl Clauberg's experimental block in Auschwitz. The krätzeblock housed prisoners with scabies infection, and the TBC block those with tuberculosis. The Schonungsblock (by Polish prisoners called "szonung") housed prisoners with minor illnesses and convalescents. There was also a block for invalids and various other wards, for example surgical wards. Apart from sick rooms (the so-called "szuby") the "rewir" also comprised a bathroom, an X-ray room, dentistry room, and pharmacy. Cf. Z Jagoda, S. Kłodziński, J. Masłowski, Osobliwości słownictwa w oświęcimskim szpitalu obozowym, "Przegląd Lekarski" 1972, no. 1, pp. 38-39.

69 AIPN Sz, SWS, OKS, file no. S/15/68/OKS, AGP, vol. 1, card 106-108 - The minutes of the testimony of witness Romuald Wieczorkowski.

70 Tadeusz Kamiński - DOB. 29.06.1924, KL Stutthof prisoner no. 35812; AMS, Akta osobowe, file no. I-III-6839; AMS, Lista transportowa więźniów przesłanych do KL Stutthof z Pawiaka 24.05.1944 r., file no. I-IIB-6.

Studia nad Autorytaryzmem i Totalitaryzmem 42, nr 1, 2020

(C) for this edition by CNS 
and the surgical ward by Eugeniusz Bojko. ${ }^{71}$ There was also a block for convalescents (schonungsblock, szonung) ${ }^{72}$ and a quarantine zone. New prisoners spent there their first few days before they were moved to their working kommandos.

Dr. Bolesław Kaczyński mentioned above was indeed a camp doctor. ${ }^{73}$ From the prisoners' point of view he also seemed to perform the function of head doctor - the head of the hospital. ${ }^{74}$ Bolesław Kaczyński was born on 20th November 1908 in Warsaw. He graduated from the State Humanistic Junior Secondary School in Drohiczyn in 1929 to continue his education in the Reserve Officer Cadet School in Cracow. In 1930 he took up medical sciences at the Medical Faculty of the Jan Kazimierz University in Lviv (Lwów) where he studied between 1930/1931 and 1935/1936. ${ }^{75}$ He completed his doctor's internship at the St. Anthony's Hospital in Lviv. Not only did Kaczyński work there as a junior doctor but he was also a doctor at the Municipal Health Faculty (from 1st February to 1st June 1939). He also practised in the Social Insurance Company (from 1st February to 1 st June 1939) as a family doctor. ${ }^{76}$

Following the outbreak of the Second World War Bolesław Kaczyński was demobilised and deployed to the sanitary service. At the end of the September Campaign, on 5th October 1939, he was captured by the Germans. His Curriculum Vitae says that he was released in the first days of November. Other sources suggest that he managed to escape. ${ }^{77}$

He then moved to Łuków, a town where his parents lived. He took a job in the local hospital there. This, however, was only one of his occupations. He was also involved with the Polish Red Cross. Additionally, he also started a job at the Health Centre in Tuchowicz. According to Maciej Lambert, Dr Bolesław Kaczyński had been actively engaged in the fight against the occupiers from the beginning of the war. He started to cooperate with the Union of Armed Struggle (Związek Walki Zbrojnej) in the first days of occupation. As a doctor he had a lot of freedom of movement. In addition to his everyday duties, he distributed leaflets, underground press, and orders. His actions were noticed by the Gestapo. His

71 Eugeniusz Bojko - DOB 21.07.1917, KL Stutthof prisoner no. 35698; AMS, Lista transportowa więźniów przesłanych do KL Stutthof z Pawiaka 24.05.1944 r., file no. I-IIB-6; AMS, Akta osobowe, file no. I-III-1580.

72 Schonungsblock (Polish "Schonungsblok" or "szonung") — a block for convalescents and patients with minor illnesses.

73 M. Gliński, Obsada szpitala obozowego w Stutthofie..., p. 70.

74 Bolesław Kaczyński - DOB. 20.11.1908, KL Stutthof prisoner no. 14701; AMS, Akta osobowe, file no. I-III-46481; AMS, Wykazy w blokach, file no. I-IIIB-2; AMS, Księga ewidencyjna, file no. I-IIE-5; AMS, Szpital obozowy, file no. I-VB-5-24; AMS, Szpital obozowy, file no. I-VB-5-1; AMS, Akta osobowe, file no. I-III-6672.

75 AIPN Sz, file no. 0019/1238, card 8, Akta personalne funkcjonariusza SB: Kaczyński Bolestaw, imię ojca Kazimierz, data urodzenia: 20.11. 1908 r., Odpis dyplomu lekarskiego.

76 P. Knap, Druga strona medalu. Bolesław Kaczyński (1908-1963), "Pamięć i Przyszłość" 2013, no. 3 .

77 M. Lambert, Dr Bolesław Kaczyński, "Przegląd Lekarski” 1972, no. 1, p. 239.

Studia nad Autorytaryzmem i Totalitaryzmem 42, nr 1, 2020

(C) for this edition by CNS 
Curriculum Vitae informs that he was arrested on 20th October 1940 and put in a prison in Lublin. However, according to another source it happened a day later, on 21 st October. ${ }^{78}$ This date could anyway be treated as a watershed in his life, as it marked a stage of his journey through camps. Initially he was sent to Auschwitz, (Oświęcim), then to Flosenbürg, Stutthof, and Aussenlager Politz.

He was sent to Pölitz at the end of June 1944. He was prisoner no. $14701^{79}$ and wore a red badge. Polish prisoners gave him a nickname "Wileńszczak" (from the Vilnius Region), though he actually came from Lublin Voivodeship.

It had not been the first time that dr. Bolesław Kaczyński had worked as a camp doctor. He learned the nature of the job before coming to Pölitz as he was held in the central camp of KL Stutthof, where he was one of the doctors attending to prisoners. In Pölitz, however, his situation was totally different. In practical terms he was the only professional doctor in the "rewir". He had assistant paramedics and male nurses, among them the already mentioned Tadeusz Kamiński and Lipcius Jonas. ${ }^{81}$ Kaczyński is pictured differently in various accounts of prisoners who went through the "hell" of camp life. Generally speaking the judgement is positive. His devotion to prisoners and carrying out medical duties in difficult circumstances is emphasised. Thanks to this, he is said to have saved the lives of some of the prisoners: "Dr Bolesław Kaczyński saved the lives of hundreds of prisoners". ${ }^{82}$ According to a different account: "I was heavily beaten up by Erich Schamp on the day of my arrival to the camp; my left arm and ribs were broken. My life was saved by a fellow prisoner, Bolesław Kaczyński (camp medic)". ${ }^{83}$ Another prisoner's statement strikes a similar tone: "I was in the hospital from December 1944 to February 1945 (Bronchitis, Scarlet Fever). I remember that people had no medicines so Dr Kaczyński stole them from the SS medicine chest. The most common diseases included diarrhoea and Phlegmon". ${ }^{84}$

78 Ibidem, p. 240; AIPN Sz. file no. 0019/1238, card 4, Akta personalne funkcjonariusza SB: Kaczyński Bolesław, imię ojca Kazimierz, data urodzenia: 20.11.1908 rok, Życiorys; AIPN Sz, file no. 009/720, card 17, Protokół przestuchania świadka Bolesława Kaczyńskiego.

79 Institute of National Remembrance in Warsaw (further: AIPN W). The Collection of the Main Commission For the Prosecution of Hitler's Crimes in Poland (futher: GKBZHwP) Camp and prisoners' files (further: Ob), Obóz koncentracyjny Stutthof (Konzentranzionslager Stutthof). Wykaz imienny 8875 więźniów obozu, których pobyt ustalono na podstawie akt, zeznań, relacji itp. Wykaz zostat sporządzony przez sędziego Antoniego Zachariasiewicza z Sądu Okręgowego w Gdańsku 1946, file no. GK 165/200; AIPN W, GKBZHwP, file no. 67912/1/123, Zbiór fotokopii dot. więźniów obozu w Stutthofie.

80 "Wileńszczak" - a person coming from the Vilnius Region.

81 Jonas Lipcius - DOB 07/03/1902, KL Stutthof prisoner no. 45060. Por. AMS Księga ewidencyjna, file no. I-VB-23-86.

82 AIPN Sz, OKBZH, file no. S/15/68/OKS, AGP, vol. 8, card 168, Protokół zeznań świadka Antoni Budziejko.

83 AIPN Sz, OKBZH, file no. S/15/68/OKS, AGP, vol. 1, card 28, Protokót zeznań świadka Czesław Głowacz.

${ }^{84}$ AIPN Sz, OKBZH, file no. S/15/68/OKS, AGP, vol. 1, card 15, Protokół zeznań świadka Stanisław Musiałowicz.

Studia nad Autorytaryzmem i Totalitaryzmem 42, nr 1, 2020

(C) for this edition by CNS 
Then there was the case of discharging prisoners from hospital to protect them from execution:

In May 1945, or rather in April 1945, the camp was to be evacuated. One of the SS-men let him know that patients would be taken away in cars. Sensing that the sick would be murdered, Dr Kaczyński discharged everybody to the camp, though he left about 350-400 of the very sick, including Poles, Russians, Italians, French, and one black man. Cars came in the morning. The sick were loaded onto them and five minutes later we heard automatic gunfire and assumed that the sick were executed. The cars returned full of spoons and bread crumbs. ${ }^{85}$

The witness accounts also state the doctor's conservative approach, largely as a result of living in the camp:

The camp had a high mortality rate. Prisoners died of malnutrition, hard work, and bad sanitary conditions. In one case, at the end of the war, Police received one more transport of about 3,000 prisoners. The doctor declared 1,800 of those as unfit to work. What happened to them I do not know. The remainder were accepted to the camp, but almost all died shortly after. ${ }^{86}$

The above account does not provide the name of the doctor, however the context allows one to assume that it was the camp doctor, Dr Bolesław Kaczyński. Such a conservative attitude is visible even more clearly in the account by another prisoner who tried various ways to survive in the harsh conditions of the camp:

I drank a lot of water deliberately in order to swell. Thanks to that I was admitted to the hospital where Dr Kaczyński even wanted to keep me as his assistant but the fear of the murderous Kozłowski made him send me off with the sick who were returning to Stutthof. I left with a group of 319 people on 23rd-25th September 1944. In Stutthof I was [selected] for evacuation on foot, I got my freedom back in March 1945 near Lębork. ${ }^{87}$

This part of witness' accounts on Dr Bolesław Kaczyński’s work as a doctor is best summarised by a statement of another prisoner who said: "Dr Bolesław Kaczyński was a camp doctor, who helped prisoners as far as it was possible". ${ }^{88}$ However, despite his best efforts, the hospital was gradually and systematically turning into a "dying house".

In a separate room there was a hospital that we called the "dying house". We were working at building shelters and removing rubble. [...] The highest mortality was among those who worked. If a column of let us say 150 people marched out of the camp, 20 of them were brought back dead or in agony, They were dying of exhaustion. ${ }^{89}$

85 Ibidem.

86 AIPN Sz, OKBZH, file no. S/15/68/OKS, AGP, vol. 4, card 189-192, Protokót zeznań świadka Albin Kirejczyk.

87 AIPN Sz, OKBZH, file no. S/15/68/OKS, AGP, vol. 1, card 4-6, Protokót zeznań świadka Antoni Stachórski.

88 AIPN Sz, OKBZH, file no. S/15/68/OKS, AGP, vol. 1, card 65, Protokót zeznań świadka Jerzy Nowicki.

89 AIPN Sz, OKBZH, file no. S/15/68/OKS, AGP, vol. 4, card 743-747 — The minutes of the testimony of witness Leon Jączyński.

Studia nad Autorytaryzmem i Totalitaryzmem 42, nr 1, 2020

(C) for this edition by CNS 
However, Dr Bolesław Kaczyński was not perceived in a one-sided way among prisoners. This ambiguity is most visible in the account by Józef Jagodziński. He presents Kaczyński directly as a 'kapo-doctor', who beat prisoners up and carried out selection:

An outstanding person was the camp doctor Bolesław Kaczyński. He cared for the sick but also simultaneously took part in selecting prisoners for death. On 17th March 1945, with him present, 145 sick prisoners were taken away from the hospital and then driven to the nearby forest and executed. The bodies were buried in that very forest [...] At the railway station in Police, doctor Kaczyński carried out a selection among 2,000 prisoners who arrived in a transport from Bergen-Belsen. Only 986 of these prisoners were accepted into the camp, the rest were executed in the nearby forest. I did not witness any of these two executions. During the first I saw it when 345 sick prisoners were being loaded into cars, which then went in the direction of a nearby forest, shortly after I heard a series of machine guns being fired [...]. ${ }^{90}$

The camp doctor keeps turning up in Jagodziński's memoirs. He is mentioned multiple times at various occasions. In his memoirs Jagodziński wrote that Kaczyński "Could have helped a lot of people indeed but in order to do that one needs the morale of Hippocrates and he lacked it. It happened often that Kaczyński hit the prisoners in the face and sent people with a raised temperature to work". ${ }^{91}$ In his memoirs he emphasised Kaczyński's acting in his own interests, helping only those whom he needed. Interestingly, Jagodziński himself admits that he had a certain obsession with doctor Kaczyński. ${ }^{92}$ In his reply to a letter to the President of the District National Council in Stargard Szczeciński in 1946, Krzysztof Dunin-Wąsowicz also explained: "My opinion about Dr Kaczyński is shaped by information and stories by my colleagues, especially Leonard Szynkiewicz and Gerard Szynkiewicz, the former already died and the latter works in the City Hall in Słupsk. They, Leonard especially, held a negative view of Kaczyński". ${ }^{93}$

Let us return now to the conditions in Aussenlager Pölitz. Catastrophic conditions in the camp made a strong impact on the high mortality and incidence rate. The hospital documentation (Lagerartz) accounted for a small number of the prisoners' deaths. In the period from October to November 1944, 106 people died in the camp hospital. ${ }^{94}$ However, taking into consideration fluctuations in the prisoners count in the sub-camp these figures raise some doubts. They are connected to, among other things, the fact that the sick and most exhausted prisoners were sent to the central camp in Stutthof.

The health conditions developed by prisoners from the KL Stutthof - Aussenlager Pölitz could be divided into 4 groups: 1) illnesses related to the living

90 J. Jagodziński, Bunkry na ruinach..., p. 77.

91 Ibidem, p. 76.

92 Ibidem, p. 77.

93 APS, Oddział w Stargardzie Szczecińskim, Starostwo pow. Stargard, file no. 175, Akta tajne 1945-1946 r., card 129-130. Also: K. Dunin-Wąsowicz, Stutthof. Ze wspomnień więźnia..., p. 48.

94 AMS, Konzentrationslager Stuthoff, file no. I-VB 7, Hospital files (Krankenbau).

Studia nad Autorytaryzmem i Totalitaryzmem 42, nr 1, 2020

(C) for this edition by CNS 
conditions in the camp, typical for most concentration camps, 2) illnesses resulting from hunger and total exhaustion, 3) injuries caused by beating, and 4) illnesses resulting from workplace contamination.

The first category included illnesses typical for concentration camps, such as typhus, ${ }^{95}$ bloody diarrhoea ${ }^{96}$ (which always led to death), phlegmon, ${ }^{97}$ tuberculosis, pediculosis, and pneumonia. Prisoners' accounts include information on this issue: "Epidemics of diseases such as Typhus broke out in the camp. The common disease, however, was so-called phlegmon". ${ }^{98}$ A separate category of health problems were conditions resulting from malnutrition or widespread famine. Hunger was omnipresent, dominant, and the most basic reason of the process of a slow death. As a result, Hitler's concentration camps "became a scene of the greatest famine tragedy in Europe". 99 The most exhausted prisoners in the Pölitz camp were called "krypel". This is Pölitz's jargon counterpart of the term "muzułman" in Auschwitz. ${ }^{100}$

95 Typhus - a disease also known as typhus fever. See M. Ciesielska, Tyfus - choroba czasu pokoju i wojny, "Niepodległość i Pamięć” 2016, no. 2 (54), pp. 93-113.

96 Bloody diarrhoea - widely known as dysentery.

97 Phlegmon - a disease involving acute inflammation of the soft tissues The symptoms included high fever, pain and swelling. The frame factors for the development of this illness included: complete exhaustion, avitaminosis, being unable to fight bacterial infections caused by minor cuts and abrasion of the skin. When untreated, the illness caused a general infection of the patient's body and subsequently led to death. Cf. http://www.70.auschwitz.org (accessed: 3.08.2019).

98 AIPN Sz, OKBZH, file no. S/15/68/OKS, AGP, vol. 2, card 15 - The minutes of the testimony of a witness Stanisław Musialik.

99 P. Helweg-Larsen et al., Famine disease in German concentration camps; complications and sequels, with special reference to tuberculosis, mental disorders, and social consequences, “Acta Psychiatr Neurol Scand Suppl." 1952, no. 83 ff.; H. Heller, S.E. Dicker, Some renal effects of experimental dietary deficiencies, "Proceeding of the Royal Society of Medicine" 40, 1947, no. 7, pp. 351-353; S. Jaspers, Nutrition, disease, and death in times of famine, "Disasters" 19, 1995, no. 2, pp. 94-109.

100 Muzułman - a twisted form of the Polish word "muzułmanin", a Muslim (Ger. Muselmann) widely used in Auschwitz and other German concentration camps. In the camp's jargon this word was used for prisoners who were extremely wasted by hunger. The "muzułman" suffered from the loss of subcutaneous fat and muscles, their dry skin brought out the line of the bones, their face resembled a mask, their eyes became bleary. Because of muscular atrophy their moves became slower, they hunched, they were keen to remain in a squatting position. When feeling cold, they covered themselves with blankets, rag, or paper from paper bags for cement. The somatic changes were followed by mental disorders. Initially a "muzułman" was hyperactive and hypersensitive, and their attention was focused only on getting food. With the passage of time, however, they became indifferent to external stimuli. During a selection in the camp they were referred to the gas chambers. Cf. http://www.70.auschwitz.org (accessed: 7.08.2019); M. Kłusak, Zachorowalność więźniów, jej przyczyny i lecznictwo w obozie koncentracyjnym Stutthof w latach 1939-1945, "Stutthof. Zeszyty Muzeum" 1976, no. 1, pp. 57-58; S. Sterkowicz, Uwagi o obozowym wyniszczeniu głodowym, "Przegląd Lekarski" 1971, no. 1, pp. 17-22; Z. Ryn, S. Kłodziński, Na granicy życia i śmierci. Studium obozowego „muzutmaństwa”, "Przegląd Lekarski” 1983, no. 40, pp. 27-43; Z. Ryn, Between life and death. Experiences of concentration camp Mussulen during the Holocaust, "Genetic, Social and General Psychology Monographs" 116, 1990, no. 1, pp. 5-19.

Studia nad Autorytaryzmem i Totalitaryzmem 42, nr 1, 2020

(C) for this edition by CNS 
Prisoners also suffered from bodily injuries caused by beating. For beating, usually a thick cable, rubber, wooden planks or lashes were used.

I remember a few such instances when prisoners died as a result of kidney failure and haemorrhage. Many prisoners died due to exhaustion resulting from hard work and hunger. In total, 30 to 60 people died every day. In summer, the mortality rate in the camps was lower. One and then two barracks were used as a hospital. The epidemic of bloody diarrhoea was a constant with no breaks at all. Five to six people died in hospital every day. I was a paramedic [words of Eugeniusz Bojko - author's note] in the hospital so I remember these facts very well — one of the prisoners recalls. ${ }^{101}$

Work was another factor significantly contributing to a rising incidence of and accelerating pace of extermination. Prisoners provided the cheapest labour available and, assuming organisation worked well, they were profitable. Prisoners of the sub-camp Pölitz were laboured to do various works, mostly in the synthetic fuel factory. They most often suffered from illnesses resulting from industrial contamination. In their work they often encountered various poisonous chemical substances. Prisoners suffered especially severely when they worked on painting fuel vessels located underground or manufacturing adhesive and tar or unloading pitch: ${ }^{102}$

The work at breaking up pitch was hard and exhausting. When it was sunny, the dust lifted into the air and it covered the faces causing burns of the skin and teary eyes. Workers often suffered from eye inflammation. And when it was rainy, grains of pitch hit the bodies like ice particulars. ${ }^{103}$

That was not the only work they did in the factory. They were also laboured to do other tasks.

Prisoners were hired for construction works at the synthetic fuel factory and to clear the rubble, build air-raid shelters and remove unexploded shells. In winter, 20 prisoners died every day. The work started at $7 \mathrm{am}$ and lasted till $5 \mathrm{pm}$. We only received two meals a day. ${ }^{104}$

It is worth noting that hospital conditions in Pölitz were worse than in the central camp. While building the camp, the Germans did not plan for any space for a hospital. In effect at the beginning it was organised into two and then three barracks adapted for medical purposes. One of the prisoners recalled:

in the "rewir" there were triple bunk beds standing so close to one another that you could not move around. There were two or three people on each bed. It was hot outside and sizzling

101 AIPN Sz, OKBZH, file no. S/15/68/OKS, AGP, vol. 1, card 74 - The minutes of the testimony of witness Eugeniusz Bojko.

102 Pitch is a by-product of processing synthetic fuel. It is mainly used to produce briquettes, roofing paper and treating road surfaces.

103 AIPN Sz, OKBZH, file no. S/15/68/OKS, AGP, vol. 9, card 96 - The minutes of the testimony of witness Kazimierz Kolasiński.

104 AIPN Sz, OKBZH, file no. S/15/68/OKS, AGP, vol. 5, card 89-90 — The minutes of the testimony of witness Arkadiusz Zimnicki.

Studia nad Autorytaryzmem i Totalitaryzmem 42, nr 1, 2020

(c) for this edition by CNS 
inside. The smell of pus and excrement was unbearable. Windows were blocked by beds so it was dark and the air was stiff. ${ }^{105}$

A lack of an adequate amount of dressings and medicines was another problem. In camp conditions prisoners covered their injuries with gauze and wrapped them with paper tape. Sometimes, especially when the number of the sick escalated, one bed in the "rewir" was occupied by three patients. ${ }^{106}$ These unimaginably harsh conditions are illustrated by a statement on the high incidence of illnesses in the Pölitz sub-camp given by one of the prisoners: "In January or February 1945 a large transport arrived from other camps and 1000 of the sick were taken away to Stutthof, and then within a month the hospital took again about 700-800 people". ${ }^{107}$

It is difficult to unambiguously assess the situation in the camp hospital. Witnesses' accounts are either ambiguous or internally contradictory. Years later some prisoners recalled that they strived for getting in there to take at least some break from the hard life at the camp. Some claimed the work was lighter there than in the synthetic fuel factory: "In December [1944 — author's note], after I was again beaten up [by Wacław Kozłowski ${ }^{108}$ — author's note] Bolesław Kaczyński treated me and allowed me to remain in his 'rewir' as an assistant cleaner". ${ }^{109}$ However, for the majority of prisoners this seemed a place they would rather avoid. In their opinion, the "hospital" was gradually becoming "the dying rooms":

In a separate room there was a hospital which we called a "doing in room". We worked on shelter construction and removing the rubble. [...] The highest mortality rate was at work. If, for example, a column of 150 people departed, then about 20 were brought back dead or in agony. They died of exhaustion. ${ }^{110}$

Pitiful food rations and intensive, exhausting work impacted heavily on the mortality rate in the camp. Moreover, the sanitary conditions in the camp were disastrous. Prisoners lived in filth and waste.

105 AIPN Sz, OKBZH, file no. S/15/68/OKS, AGP, vol. 1, card 28 - The minutes of the testimony of witness Czesław Gołowacz.

106 J. Nowicki (a former prisoner of concentration camps in Stutthof and Pölitz), Od Stutthofu do Sandbostel, "Przegląd Lekarski" 1968, no. 1, p. 160.

107 IPN Sz, SWS, OKS, AGP, file no. vol. 1, card 106-108 - The minutes of the testimony of witness Romuald Wieczorkowski.

108 Wacław Kozłowski - DOB 01/09/1903, KL Stutthof prisoner no. 7029, he served as a Lagerältester I (camp senior) in the Pölitz camp. According to witness accounts he was exceptionally brutal towards other prisoners. In 1946, a Special Criminal Court in Gdańsk sentenced him for his conduct in the camp to death by hanging. The sentence was carried out. It was the first of four trials of the Stutthof crew that took part from 25th April to 1st June 1946.

109 AIPN Sz, OKBZH, file no. S/15/68/OKS, AGP, vol. 1, card 113 ff. — The minutes of the testimony ofa witness Romuald Wieczorkowski.

110 AIPN Sz, OKBZH, file no. S/15/68/OKS, AGP, vol. 4, card 743-747 - The minutes of the testimony of witness Leon Jączyński.

Studia nad Autorytaryzmem i Totalitaryzmem 42, nr 1, 2020

(C) for this edition by CNS 
Sanitation and hygienic conditions were really poor. We were given no soap. A large number of insects (louses and bed bugs) lived in barracks and blankets. Prisoners slept on plank beds without mattresses. There were no bedsheets. Once a month underwear and clothes were deloused. You could only take a cold bath. ${ }^{11}$

\section{Conclusion}

The camp hospital in KL Stutthof Pölitz met with a tragic end. Just before the liberation and evacuation, all prisoners from the "rewir" were executed in a nearby forest:

Early in the morning at the beginning of April 1945 three lorries with SS soldiers arrived at the hospital barracks and they told the doctor — dr Kaczyński — that the sick would be evacuated and should dress as quickly as possible because the carriages were awaiting them at the railway station. The sick were brutally packed onto the lorries and taken away to an unknown destination. 10-15 minutes following their departure to the south-west machine guns were heard from there. I gather the sick were executed. Soon the cars came back and took another group of the sick, then gunshots were heard again from the same direction. The cars went there and back perhaps four times. All the sick, about 700 of them, were taken away. ${ }^{112}$

A complete evacuation took place on 23rd April 1945. ${ }^{113}$ A remaining 25 sick prisoners and 30 others were left behind to do the cleaning works. According to dr. Kaczyński and Lipcius, a paramedic, the sick were shot and their bodies were burned. ${ }^{114}$ Dr. Kaczyński left the camp in Pölitz with the last column of prisoners. At the beginning of May 1945 he arrived in Szczecin together with a group of concentration camp prisoners still wearing striped prison uniforms. ${ }^{115} \mathrm{He}$ almost

111 AIPN Sz, OKBZH, file no. S/15/68/OKS, AGP, vol. 3, card 123 ff. — The minutes of the testimony of witness Emil Witold Mildner.

112 AIPN Sz, OKBZH, file no. S/15/68/OKS, AGP, vol. 1, card 75 - The minutes of the testimony of witness Eugeniusz Bojko.

113 The evacuation of prisoners from the area of Szczecin had already begun in February 1945. In March about 800 prisoners were sent to Bergen-Belsen and more than 300 sick prisoners were executed. Then in April 400 other prisoners were taken to Barth, and then evacuated towards Rostock. On 23rd April 1945 the remaining prisoners were evacuated to Tanow, near Police, and then to Ueckermünde. Only a few prisoners remained in Aussenlager Politz. Cf. M. Orski, Filie..., p. 312; P. Szulc, op. cit., p. 45; K. Golczewski, Przymusowa ewakuacja z nadbattyckich prowincji III Rzeszy 1944-1945, Poznań 1971, p. 145.

114 AIPN Sz, OKBZH, file no. S/15/68/OKS, AGP, vol. 1, card 85 - The minutes of the testimony of witness Józef Jagodziński. According to Maciej Lambert the majority of prisoners who remained in Aussenlager Politz were taken away to Szczecin and burned in a crematorium at the local Central Cemetery. The remainder were executed on the side of the road and their bodies were buried in a forest near Police. Cf. M. Lambert, Niektóre problemy medyczne..., p. 1.

115 M. Lambert, Jubileusz, "Nowy Medyk" 1970, no. 9, p. 4. B. Frankiewicz reports that 232 prisoners were shot dead and 400 more were chased away in a 'march of death'. Cf. B. Frankiewicz, Obozy hitlerowskie na Pomorzu Zachodnim..., p. 59; Cf. APS, Bogdan Frankiewicz's Collection, file no. 305, Hitlerowski system obozowy w Policach, card 151.

Studia nad Autorytaryzmem i Totalitaryzmem 42, nr 1, 2020

(C) for this edition by CNS 
immediately engaged in the organisation of a health service. He became the deputy of the Municipal Health Faculty's head Zygmut Jakubowski, who arrived in the city a few days earlier with the first group of technical staff. Later he was sent to Stargard where he helped to rebuild a destroyed hospital together with Dr Stanisław Kublecki who then held the post of a district doctor. ${ }^{116}$ In $1945-$ 1948 Dr Kaczyński also held the position of a doctor at the District Public Security Office in Stargard Szczecinski. Why he made such a decision is unknown. Howeverr, it seems that it was not due to ideological or political reasons but he rather had professional ones. It also could not be excluded that in his own view and taking into consideration his underground (pro-independence) activity in the times of occupation, the job at 'the secret police' could give him protection and guarantee a 'safe haven' in a new post-war reality. Let us remind ourselves that Kaczyński was sent to a concentration camp as a political prisoner. He worked in Stargard Szczecinski as a city hospital director until 15th August 1950. Then by virtue of a resolution of the Regional Board of the National Council he was deployed to work in the Chojna district where he held the position of a district hospital director. ${ }^{117} \mathrm{He}$ was later sent to Dębno Lubuskie where he performed the duties of a district hospital director, the head of a local Ambulance Station and held a job at a District Outpatient Clinic of the State Public Security Office (until $1962)^{118}$ Dr Kaczyński died on 27th January 1963. ${ }^{119}$

In the collective memory of residents of Police, maintained for years by local historians (e.g. Maciej Lambert and Jan Matura), ${ }^{120}$ Dr Bolesław Kaczyński remained a "heroic doctor" who was saving lives in the camp. In 2003 he became a patron of the Second Primary School in Police and there is a memorial room where a commemorative plate is devoted to him.

116 APS, Urząd Wojewódzki Szczeciński (further: UWS), file no. 101, card 9, Szczegółowe opisy powiatów pod względem organizacji stużby zdrowia [1945].

117 IPN Sz, file no. 0019/1238, card 10, Akta personalne funkcjonariusza SB: Kaczyński Bolesław, imię ojca Kazimierz, data urodzenia: 20.11.1908 rok [Copy of a resolution].

118 IPN Sz, file no. 0019/1238, card 11-14, Akta personalne funkcjonariusza SB: Kaczyński Bolesław, imię ojca Kazimierz, data urodzenia: 20.11.1908 rok, Zaświadczenie wydane przez Szpital powiatowy w Dębnie z dnia 5 października 1956 roku.

119 A few years later the Territorial Commission For the Prosecution of Crimes Against The Polish Nation in Szczecin became interested in the doctor during their research on the crimes committed in Aussenlager Pölitz. It turned out that Dr Kaczyński wrote a camp diary that was lost (or was destroyed/burned by Kaczyński himself) already during the war. Cf. P. Knap, op. cit., pp. 43-44.

120 Maciej Lambert in the already quoted publications (idem, Dr Bolesław Kaczyński, "Przegląd Lekarski" 1972, no. 1; idem, Jubileusz...; idem, Warunki sanitarno-higieniczne...) was almost absolutely uncritical about Kaczyński. Similarly Jerzy Nowicki, an Aussenlager Pölitz prisoner, in his published memoirs. Cf. J. Nowicki, op. cit. Jan Matura, a regional historian from Police also presented him in a one-sided way, repeating what Lambert had established, cf. idem, Historia Polic od czasów najstarszego osadnictwa do II wojny światowej, Police 2002, pp. 143-150. P. Knap (op. cit.) was the first to present the figure of a camp doctor and his post-war activities in a more nuanced manner.

Studia nad Autorytaryzmem i Totalitaryzmem 42, nr 1, 2020

(C) for this edition by CNS 
The operation of the Pölitz camp may be divided into two periods: one when the camp (at that time "the summer camp") was still under construction, and the other - its actual operation - when the winter camp was established with extended camp infrastructure. However, regardless of the time, prisoners always suffered from hunger, exhausting work beyond their capabilities and various illnesses. The camp doctor played an important role in attending to patients. In the case of the Pölitz camp that role was in fact played by dr. Bolesław Kaczyński. As a medical doctor and regardless of the circumstances he was obliged to obey the universal rules of medical and deontological ethics. However, following them in the camp conditions was often difficult and sometimes even impossible. With the passage of time each camp developed its own informal and unwritten rules of

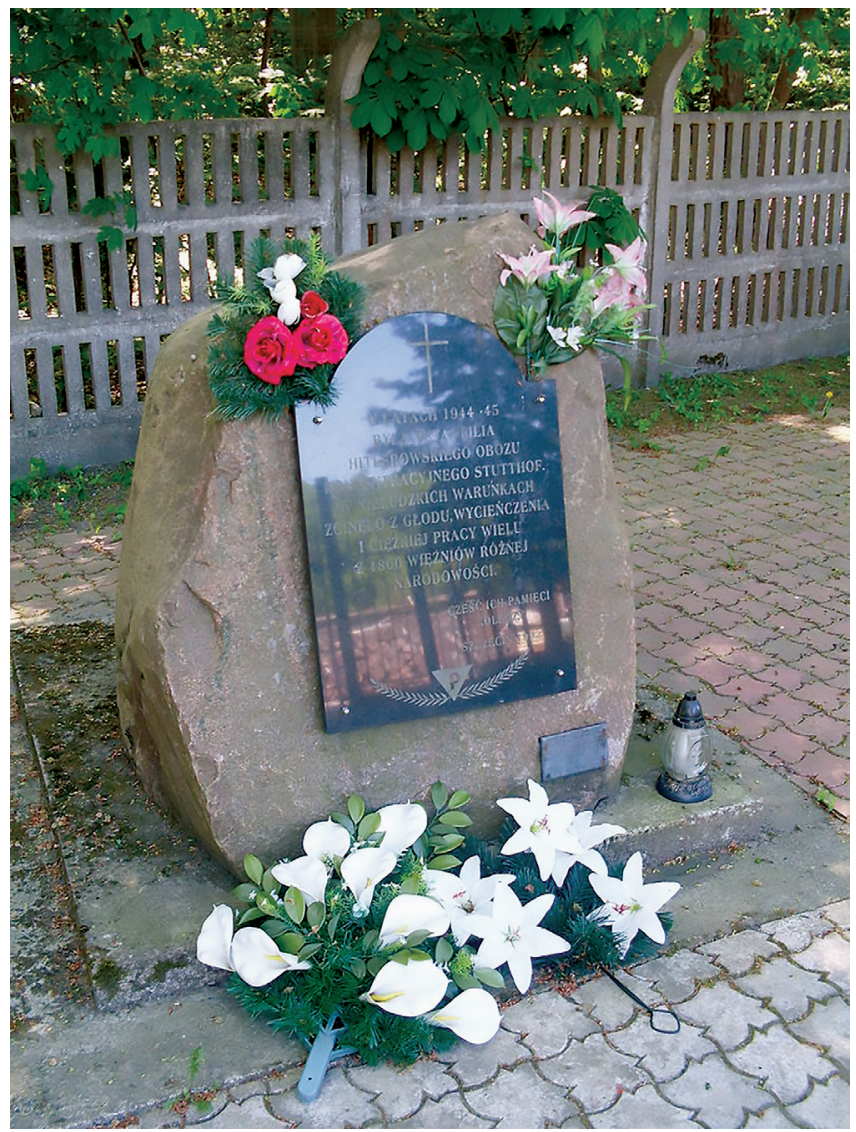

Illustration 1. Aussenlager Pölitz prisoners memorial

Source: https://pl.wikipedia.org/wiki/M\%C5\%9Bci\%C4\%99cino

(accessed: 23.01.2020), photo by MMich, CC BY-SA 4.0. 
conduct and, whether willingly or unwillingly, they were obeyed. Kaczyński was aware of that. Lack of medicines, medical dressings or beds in the hospital for all who needed them persuaded him to perform a "natural selection", ${ }^{121}$ that is help first of all those who had any chance to survive. When the war ended the area of Aussenlager Pölitz housed a pig farm (from 1950). In 1980 the area was passed on to the Municipal Cooperative Police to house construction materials warehouses, car repair shops, paint shops, a tyre service and metalwork. This so-called Craftsmen Estate existed until 2017.

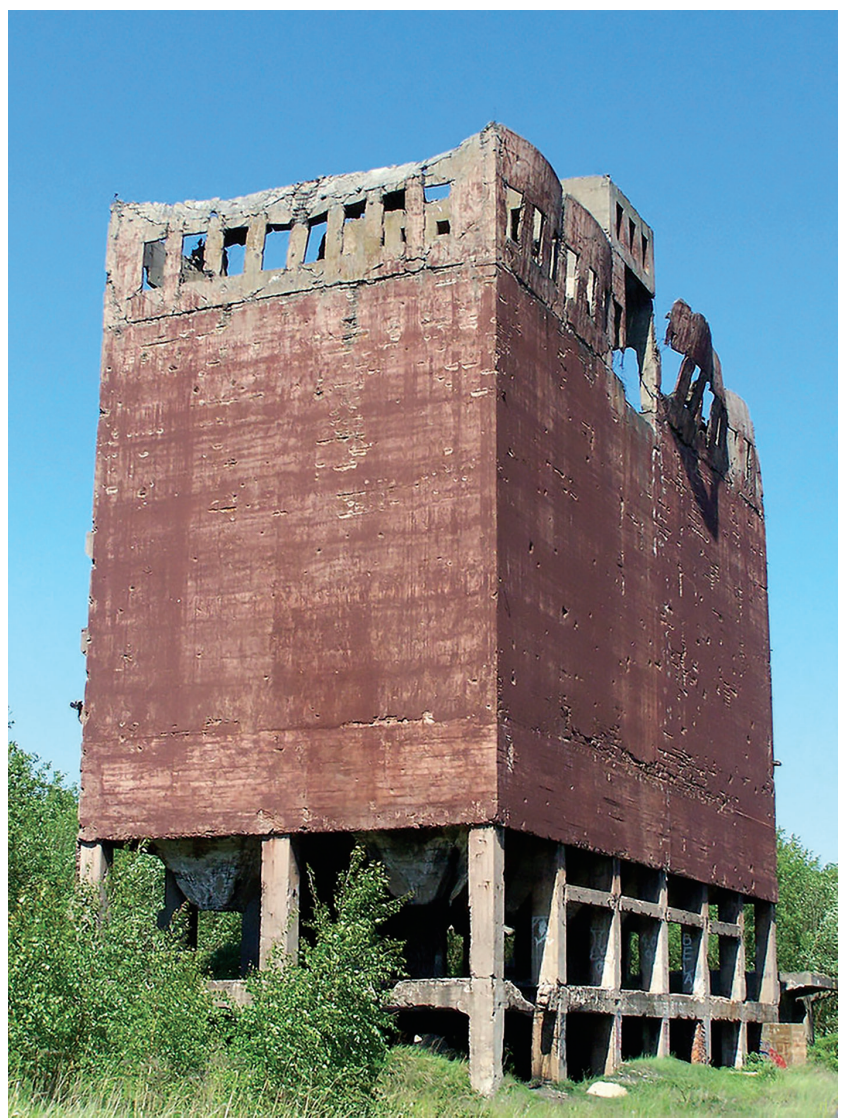

Illustration 2. Coal hoister. Synthetic Fuel Factory in Police

Source: https://pl.wikipedia.org/wiki/Fabryka_benzyny_syntetycznej_w_ Policach\#/media/Plik:ElewatorWeglowyPolice.jpg (accessed: 23.01.2020), photo by Remigiusz Józefowicz, CC BY-SA 2.5 PL.

121 S. Kołodziński, Niektóre zagadnienia deontologii lekarskiej w hitlerowskich obozach koncentracyjnych, "Przegląd Lekarski" 1963, no. 1, p. 101.

Studia nad Autorytaryzmem i Totalitaryzmem 42, nr 1, 2020

(C) for this edition by CNS 


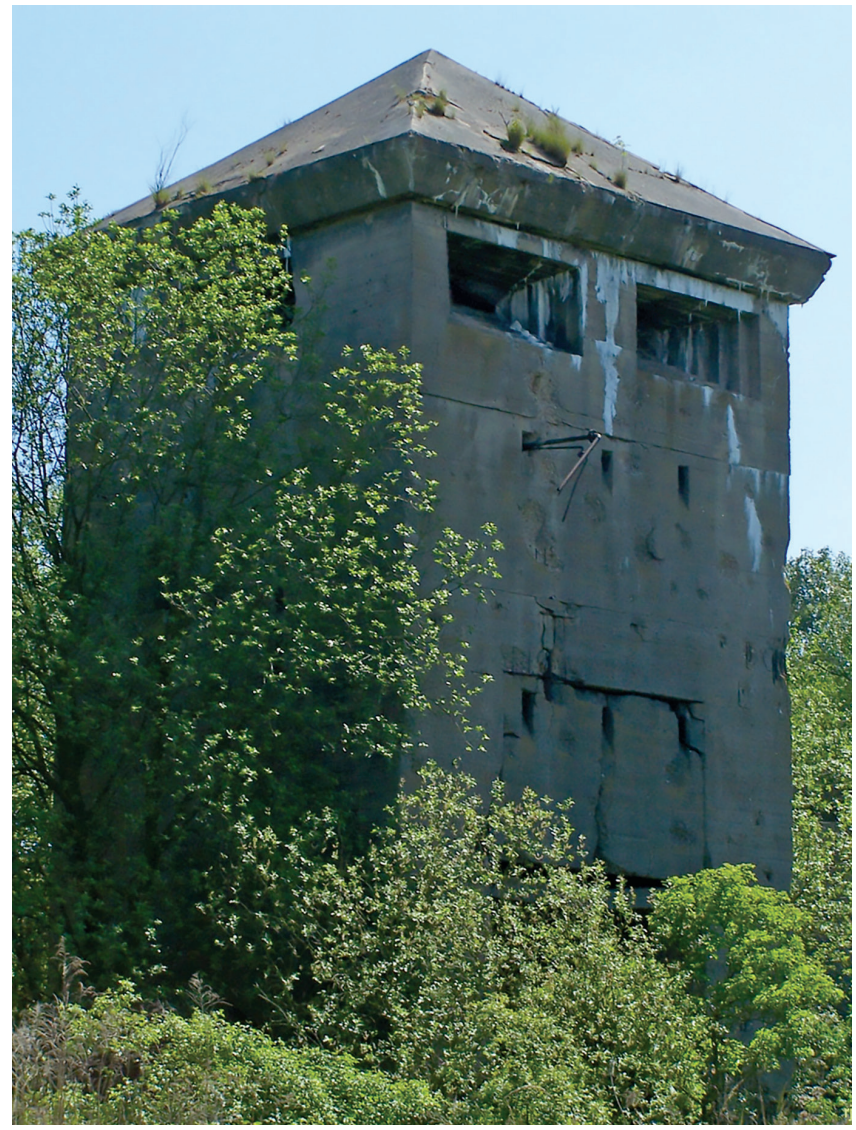

Illustration 3. Watchtower. Synthetic Fuel Factory in Police

Source: https://pl.wikipedia.org/wiki/Plik:WiezaWartowniczaPolice.jpg (accessed: 23.02.2020), photo by Remigiusz Józefowicz, CC BY-SA 2.5 PL.

\section{Bibliography}

\section{Sources}

\section{Archival materials}

Archives of the Branch Office of the Commission For the Prosecution of Crimes Against The Polish Nation of the Institute of National Remembrance in Szczecin (AIPN Sz, OKBZH).

Lambert M., Niektóre problemy medyczne obozu koncentracyjnego w Mścięcinie, file no. 5/128, mps.

Personal Files [Akta personalne] of Security Police functionary: Kaczyński, Bolesław, father's name: Kazimierz, born: 20.11.1908, file no. 0019/1238.

Studia nad Autorytaryzmem i Totalitaryzmem 42, nr 1, 2020

(C) for this edition by CNS 
Prosecutor's Main Acts [Akta Główne Prokuratora, AGP], W sprawie zbrodni hitlerowskich popetnianych wobec robotników przymusowych i jeńców wojennych osadzonych $w$ obozach karnych i pracy przymusowej na terenie Polic i okolicznych miejscowości, file no. S/15/68/OKS, vol. I-VIII.

\section{Archives of Stutthof Museum (AMS)}

Akta osobowe, file no. I-III-1580.

Akta osobowe, file no. I-III-6672.

Akta osobowe, file no. I-III-6839.

Akta osobowe, file no. I-III-46481.

Konzentrationslager Stuthoff. Hospital files (Krankenbau), file no. I-VB-7.

Księga ewidencyjna, file no. I-IIE-5.

Księga ewidencyjna, file no. I-IIE-6.

Księga ewidencyjna, file no. I-VB-23-86.

Lista transportowa więźniów przesłanych do KL Stutthof z Pawiaka 24.05.1944 r., file no. I-IIB-6.

Sonderbefehl über die Eintichtung des Aussenlagers Pöliz b. Stettin, file no. I-IB-3.

Szpital obozowy, file no. I-VB-5-1.

Szpital obozowy, file no. I-VB-5-24.

Wykazy w blokach, file no. I-IIIB-2.

\section{Institute of National Remembrance in Warsaw (AIPN W)}

The Collection of the Main Commission For the Prosecution of Hitler's Crimes in Poland (GKBZHwP) Camp and prisoners' files (Ob), Obóz koncentracyjny Stutthof (Konzentranzionslager Stutthof). Wykaz imienny 8875 więźniów obozu, których pobyt ustalono na podstawie akt, zeznań, relacji itp. Wykaz zostat sporządzony przez sędziego Antoniego Zachariasiewicza z Sądu Okręgowego w Gdańsku 1946, file no. GK 165/200.

Zbiór fotokopii dot. więźniów obozu w Stutthofie, file no. 67912/1/123.

\section{State Archives in Szczecin (APS)}

Acts of the city of Szczecin, section no. 1488a.

Bogdan Frankiewicz's Collection, file no. 305.

Szczecin's Regional (Voivdship) Office, Szczegółowe opisy powiatów pod względem organizacji stużby zdrowia [1945], file no. 101.

State Archives in Szczecin (APS). Local office in Stargard SzczecińskiCounty Office Stargard, Akta tajne 1945-1946r., file no. 175.

\section{Recollections and memoirs}

Dunin-Wąsowicz K., Stutthof. Ze wspomnień więźnia obozu koncentracyjnego, Gdańsk 2011.

Gajdus W., Nr 29998 opowiada, Kraków 1962.

Gębik W., Z diabłami na ty, Gdańsk 1972.

Jagodziński J., Bunkry na ruinach. Szkice do historii KL Stutthof - Aussenlager Pölitz, Szczecin 2009.

Mitura W., Wspomnienia więźnia Stutthofu, Warszawa 1978.

Nowicki J., Od Stutthofu do Sandbostel, "Przegląd Lekarski” 1968, no. 1.

Sruoga B., Los więźniów, Gdynia 1965.

Walle O.R., Norsk politi biggtrad. Stutthof - Polities Historie 1939-1945, Oslo 1946.

Wnuk W., Bytem z wami, Warszawa 1975. 


\section{Subject literature}

Alton R., Deportiert von den Nazis. Berlin — Lodz - Auschwitz - Stutthof - Dresden, Bielefeld 2009.

Benz W., Distel B., Der Ort des Terrors. Geschichte der nationalsozialistischen Konzentrationslager, München 2005-2009.

Birger T., Im Angesicht des Feuers. Wie ich der Hölle des Konzentrationslagers entkam, München 1990.

Blatman D., The Death Marches. The Final Phase of Nazi Genocide, Cambridge, MA 2011.

Blatman D., Les marches de la mort: la dernière étape du génocide nazi: été 1944-printemps 1945, Paris 2009.

Blitz M., Endzeit in Ostpreußen. Ein beschwiegenes Kapitel des Holocaust, Berlin 2010.

Chyrek A., Numeracja i sposób oznaczania więźniów w obozie Stutthof, "Pamięć i Sprawiedliwość" 2006, no. 2 (10).

Ciechanowski K., Geneza obozu w Stutthof - obozy internowania na Pomorzu Gdańskim od września 1939 r. do marca 1940 r., [in:] K. Ciechanowski et al., Stutthof: hitlerowski obóz koncentracyjny, Warszawa 1988.

Ciechanowski K. et al., Stutthof: hitlerowski obóz koncentracyjny, Warszawa 1988.

Ciesielska M., Szpital obozowy dla kobiet w KL Auschwitz-Birkenau (1942-1945), Warszawa 2015.

Ciesielska M., Tyfus - choroba czasu pokoju i wojny, "Niepodległość i Pamięćc" 2016, no. 2 (54).

Czerkawski A., Dunin-Wąsowicz M., Wat Pomorski, Warszawa 1970.

Drywa D., Zagłada Żydów w obozie koncentracyjnym Stutthof (wrzesień 1939-maj 1945), Gdańsk 2001.

Dunin-Wąsowicz K., Obóz koncetracyjny Stutthof, Gdynia 1966; 2nd ed. — Gdańsk 1977.

Dunin-Wąsowicz K., Police, Warszawa 1974.

Dunin-Wąsowicz K., Ruch oporu w hitlerowskich obozach koncetracyjnych 1933-1945, Warszawa 1983.

Dunin-Wąsowicz K., Stutthof, Warszawa 1981.

Fejkel W., O stużbie zdrowia w obozie koncentracyjnym, "Przegląd Lekarski" 1961, no. 1.

Fejkel W., Więźniarski szpital w KL Auschwitz, Oświęcim 1994.

Ferenc E., Budowa i rozbudowa obozu koncentracyjnego Stutthof (2.09.1939-31.12.1944), [in:] Stutthof hitlerowski obóz zagłady, ed. K. Ciechanowski et al., Warszawa 1988.

Fiuk P., Zarys historii Polic i dawnej fabryki benzyny syntetycznej - Hydrierwerke Politz - Aktiengesellschaft, "Przestrzeń i Forma" 2007, no. 5.

Frankiewicz B., Cudzoziemscy robotnicy przymusowi w Szczecinie w latach 1939-1945, "Kronika Szczecina" 2001, no. 20.

Frankiewicz B., Hitlerowskie obozy pracy przymusowej oraz obozy karne i jenieckie na terenie Szczecina w latach drugiej wojny światowej, "Przegląd Zachodniopomorski" 1965, no. 4.

Frankiewicz B., Materiały do dziejów polskich i cudzoziemskich robotników przymusowych w Archiwum Państwowym w Szczecinie, "Szczeciński Informator Archiwalny" 1999, no. 9.

Frankiewicz B., Obozy hitlerowskie na Pomorzu Zachodnim 1939-1945, [in:] Obozy hilerowskie na Pomorzu Zachodnim i Gdańskim w latach drugiej wojnyś światowej, ed. L. Janiszewski, Szczecin 1989.

Frankiewicz B., Obozy hitlerowskie na ziemi szczecińskiej w latach 1939-1945, "Studia nad Faszyzmem i Zbrodniami Hitlerowskimi” 2, 1975.

Frankiewicz B., Praca przymusowa na Pomorzu Zachodnim, w latach II wojny światowej, Poznań 1969.

Georg E., Die wirtschaftlichen Unternehmungen der SS, "Schriftenreihe der Vierteljahrshefte für Zeitgeschichte" 1963, no. 7.

Studia nad Autorytaryzmem i Totalitaryzmem 42, nr 1, 2020

(C) for this edition by CNS 
Gliński M., Obsada szpitala obozowego w Stutthofie, "Przegląd Lekarski" 1971, no. 1.

Gliński M., Organizacja i obsada personalna szpitala w obozie koncentracyjnym Sztutthof, "Stutthof. Zeszyty Muzeum" 1976, no. 1.

Gliński M., Organizacja obozu koncentracyjnego Stutthof (1 września 1939-9 maja 1945), "Stutthof. Zeszyty Muzeum" 1979, no. 3.

Gliński M., Podobozy i większe komanda zewnętrzne KL Stutthof (1939-1945), [in:] K. Ciechanowski et al., Stutthof: hitlerowski obóz koncentracyjny, Warszawa 1988.

Gliński M., Podobozy obozu Stutthof, [in:] Obozy hitlerowskie na ziemiach polskich. Informator encyklopedyczny, Warszawa 1979.

Gliński M., Załoga obozu koncentracyjnego Stutthof (1 IX. 1939-9 V 1945), part I. A-J, „Stutthof. Zeszyty Muzeum"1984, no. 5.

Gliński M., Załoga obozu koncentracyjnego Stutthof (1 IX 1939-9 V 1945), part II. K-Q, "Stutthof. Zeszyty Muzeum"1985, no. 6.

Gliński M., Załoga obozu koncentracyjnego Stutthof (1 IX 1939-9 V 1945), part III. R-Z (updated), "Stutthof. Zeszyty Muzeum” 1987, no. 7.

Golczewski K., Przymusowa ewakuacja z nadbałtyckich prowincji III Rzeszy 1944-1945, Poznań 1971.

Gołowacz C., Na miejscu kaźni w Policach, "Wolność i Lud” 1964, no. 3 (216).

Grabowska J., Marsz śmierci. Ewakuacja piesza więźniów KL Stutthof i jego podobozów 25 stycznia-3 maja 1945, Gdańsk 1992.

Grabowska J., Stutthof — Ein Konzentrationslager vor den Toren Danzigs, Bremen 1995.

Grabowska J., Kuhn H., K.L. Stutthof - Ein historischer Abriss, Bremen 1993.

Grot E., Rejs śmierci. Ewakuacja morska więźniów KL Stutthof 1945 r., Gdańsk 1993.

Heller H., Dicker S.E., Some renal effects of experimental dietary deficiencies, "Proceeding of the Royal Society of Medicine" 40, 1947, no. 7.

Helweg-Larsen P., Hoffmer H., Kieler J., Hess Thaysen E., Hess Thaysen J., Thygesen P., Hertel Wulff M.H., Famine disease in German concentration camps; complications and sequels, with special reference to tuberculosis, mental disorders and social consequences, "Acta Psychiatr. Neurol. Scand Suppl” 1952, no. 83.

Herbert U., Ort K., Dieckmann Ch., Die nationalsozialistischen Konzentrationslager: Entwicklung und Struktur, vol. 1, Göttingen 1998.

Jagoda Z., Kłodziński S., Masłowski J., Osobliwości słownictwa w oświęcimskim szpitalu obozowym, "Przegląd Lekarski" 1972, no. 1.

Jasiński A., Przełamanie Wału Pomorskiego, Warszawa 1958.

Jaspers S., Nutrition, disease and death in times of famine, "Disasters" 19, 1995, no. 2.

Jezierska M., Obozy w Policach, "Biuletyn Głównej Komisji Badania Zbrodni Hitlerowskich w Polsce" $15,1965$.

Jezierska M., Ucieczki z obozu koncentracyjnego Stutthof na tle dokumentów, "Stutthof. Zeszyty Muzeum" 1990, no. 10.

Jezierska M., Zagadnienie małych obozów, "Przegląd Lekarski” 1967, no. 1.

Kamiński A.J., Hitlerowskie obozy koncentracyjne i ośrodki masowej zagłady w polityce imperializmu niemieckiego, Poznań 1964.

Kaniewski W., Odpowiedzialność karna sprawców zbrodni popetnionych w Konzentrationslager Stutthof, "Pamięć i Sprawiedliwość" 40, 1997/1998.

Klee E., Medycyna III Rzeszy i jej ofiary, expl. E. Kalinowska-Styczeń, Kraków 2011.

Kłodziński S., Zbrodnicze doświadczenia farmakologiczne na więźniach obozu koncentracyjnego w Oświęcimiu, "Przegląd Lekarski" 1965, no. 1.

Kłusak M., Zachorowalność więźniów, jej przyczyny i lecznictwo w obozie koncentracyjnym Stutthof w latach 1939-1945, "Stutthof. Zeszyty Muzeum" 1976, no. 1. 
Kłys A., Z Pawiaka do Polic. Więźniowie z Pawiaka w obozie koncentracyjnym Stutthof i podobozie Police k/Szczecina, "Niepodległość i Pamięć" 2015, no. 4 (52).

Kłys A., Z Pawiaka do Polic. Więźniowie z Pawiaka w obozie koncentracyjnym Stutthof i podobozie Police k/Szczecina, [in:] Historia - ludzie — pamięć, ed. T. Skoczek, Warszawa 2016.

Kłys J.A., Außenlager Stutthof, "Zabytki” 6-7, 2008.

Knap P., Druga strona medalu. Bolesław Kaczyński (1908-1963), "Pamięć i Przyszłość” 2013, no. 3. Kogon E., Der SS-Staat. Das System der deutschen Konzentrationslager, Frankfurt am Main 1965. Kołodziński S., Niektóre zagadnienia deontologii lekarskiej w hitlerowskich obozach koncentracyjnych, "Przegląd Lekarski" 1963, no. 1.

Kospath-Pomorski E., Wat Pomorski 1945, Warszawa 1995.

Kowalczykowa J., Choroba głodowa w obozie koncentracyjnym w Oświęcimiu, "Przegląd Lekarski" 1961 , no. 1 .

Lambert M., Jubileusz, "Nowy Medyk” 1970, no. 9.

Lambert M., Warunki sanitarno-higieniczne $w$ obozach pracy przymusowej $w$ rejonie Szczecina w latach II wojny światowej, "Przegląd Zachodniopomorski” 1972, no. 3.

Lasik A., Sztafety ochronne w systemie niemeckich obozów koncntracyjnych, Oświęcim 2007.

Makowski A., Organizacja, rozwój i działalność szpitala więźniarskiego w Monowicach (KL Auschwitz III), "Zeszyty Oświęcimskie" 1974, no. 15.

Matura J., Historia Polic od czasów najstarszego osadnictwa do II wojny światowej, Police 2002.

Matussek P., Internment in Concentration Camps and Its Consequences, Berlin-Hamburg-New York 1975.

Matynia J., Literatura i materiały źródłowe o filiach obozu koncentracyjnego Stutthof, "Gdańskie Zeszyty Humanistyczne. Seria Pomorzoznawcza" 1969, no. 18.

Medycyna w cieniu nazizmu, ed. M. Musielak, K.B. Głodowska, Poznań 2015.

Mikulski J., Medycyna hitlerowska w stużbie III Rzeszy, Warszawa 1981.

Miniewicz J., Perzyk B., Wat Pomorski, Warszawa 1997.

Okoniewska K., Zbrodniczy medycy. Lekarze Auschwitz, Łódź 2017.

Olbrycht J., Sprawy zdrowotne w obozie koncentracyjnym w Oświęcimiu, "Przegląd Lekarski” 1962, no. 1.

Orski M., Amerykanie w obozie koncentracyjnym Stutthof, Gdańsk 1996.

Orski M., Belgowie, Holendrzy i Luksemburczycy w obozie koncentracyjnym Stutthof, Gdańsk 1996.

Orski M., Il campo di concentramento di Stutthof (1939-1945), Mediolan 2010.

Orski M., Filie obozu koncentracyjnego Stutthof w latach 1939-1945, Gdańsk 2004.

Orski M., Niewolnicza praca więźniów obozu koncentracyjnego Stutthof w latach 1939-1945, Gdańsk 1999.

Orski M., Obywatele francuscy $w$ obozie koncentracyjnym Stutthof w latach 1941-1945, Gdańsk 2010.

Orski M., Organisation und Ordnungsprinzipien des Lagers Stutthof, [in:] Die nationalsozialistischen Konzentrationslager: Entwicklung und Struktur, ed. U. Herbert, K. Orth, Ch. Dieckmann, Göttingen 1998.

Orski M., Włosi w obozie Koncentracyjnym Stutthof, Gdańsk 1996.

Orski M., Wykaz podobozów i większych komand zewnętrzych, [in:] K. Ciechanowski et al., Stutthof: hitlerowski obóz koncentracyjny, Warszawa 1988.

Orth K., Die Konzentrationslager-SS, München 2004.

Orth K., Die Konzentrationslager-SS. Soziokulturelle Analysen und biographische Studien, Göttingen 2000.

Owsiński M., Polscy więźniowie polityczni w obozie Stutthof 1939-1945, Toruń 2001.

Owsiński M., Sprawca w propagandzie medialnej na przykładzie pierwszego procesu stutthofskiego, kwiecień-maj 1946, [in:] Jak rodzi się zło? Sprawcy, wykonawcy, pomocnicy, ed. A. Bartuś, Oświęcim 2018.

Studia nad Autorytaryzmem i Totalitaryzmem 42, nr 1, 2020

(C) for this edition by CNS 
Przyłucka M., Praca więźniów w obozie koncentracyjnym Stutthof, "Stutthof. Zeszyty Muzeum" 1977, no. 2.

Ruth A., Deportiert von den Nazis, Berlin - Lodz - Auschwitz - Stutthof - Dresden, Bielefeld 2009.

Ryn Z., Between life and death. Experiences of concentration camp Mussulen during the Holocaust, "Genetic, Social and General Psychology Monographs" 116, 1990, no. 1.

Ryn Z., Death and dying in the concentration camp, "American Journal of Social Psychiatry" 1983, no. 3 .

Ryn Z., Medycyna obozów koncentracyjnych i jenieckich w piśmiennictwie zachodnim, "Przegląd Lekarski” 1985, no. 42.

Ryn Z., Kłodziński S., Głód w obozie koncentracyjnym, "Przegląd Lekarski” 1984, no. 41.

Ryn Z., Kłodziński S., Na granicy życia i śmierci. Studium obozowego „,muzułmaństwa”, "Przegląd Lekarski" 1983, no. 40.

Schmidt H., Die Gerettete Freude. Eines jungen Menschen Zeit 1925-1945, Potsdam-Babelsberg 2001.

Schwarz G., Die Nationalsozialistischen Lager, Frankfurt am Main 1997.

Siniecki B., Z historii szpitala obozowego w Sztutthofie, "Przegląd Lekarski" 1975, no. 1 (reprinted in: Okupacja i medycyna. Trzeci wybór artykułów z "Przeglądu Lekarskiego" - Oświęcim z lat 1963-1976, Warszawa 1977).

Sobczak K., Bitwa o Wat Pomorski: spojrzenie z perspektywy półwiecza, "Kronika Wielkopolska" 1995, no. 1.

Sterkowicz S., Uwagi o obozowym wyniszczeniu głodowym, "Przegląd Lekarski" 1971, no. 1.

Sterkowicz S., Zbrodnie hitlerowskiej medycyny, Warszawa 1987; 2nd ed. - Warszawa 1990.

Strzelecka I., Eksterminacyjna funkcja szpitali obozowych w KL Auschwitz, "Przegląd Lekarski" 1990, no. 1.

Strzelecka I., Medical crimes. The hospitals in Auschwitz, Oświęcim 2008.

Strzelecka I., Medical crimes. Medical experiments in Auschwitz, Oświęcim 2008.

Strzelecka I., Oddział kobiecy w męskim obozie macierzystym, "Zeszyty Oświęcimskie" 1993, no. 20.

Strzelecka I., Rozwój szpitali obozowych w Oświęcimiu-Brzezince, "Przegląd Lekarski" 1984, no. 1.

Szulc P., Polickie obozy w latach drugiej wojny światowej, [in:] Z dziejów Polic, Szczecin-Police 2007.

Toczewski A., Bitwa o Odrę w 1945 roku, Zielona Góra 2010.

Wachsmann N., Historia nazistowskich obozów koncentracyjnych, trans. M. Antosiewicz, Warszawa 2016.

Waluk B., Obozy pracy przymusowej i karne obozy pracy w Policach k. Szczecina 1939-1945, [in:] Z problematyki medycyny w hitlerowskich obozach koncentracyjnych, Gdańsk 1971.

Waluk B., Obóz koncentracyjny w Policach-Mścięcinie k. Szczecina (filia obozu koncentracyjnego Stutthof) 27 VI 1944-26 IV 1945 r., [in:] Z problematyki medycyny w hitlerowskich obozach koncentracyjnych, Gdańsk 1971.

Waxchsmann N., Historia nazistowskich obozów koncentracyjnych, Warszawa 2016.

Zientarski A., Obozy hitlerowskie na Pomorzu Zachodnim w okresie 1939-1940, "Biuletyn Głównej Komisji Badania Zbrodni Hitlerowskich w Polsce” 31, 1982. 